\title{
The Police Officer's Plight: The InTERsection OF POLICING AND THE LAW
}

\author{
KEVIN CYR ${ }^{*}$
}

The article examines the interaction and tension between the attitudes of the police and the courts in the context of the criminal justice system. Canadian laws governing the authority of the police are argued to be generally permissive but lacking in clear and specific definition. Because of this, their application may be highly subjective which causes problems when the police and the courts have different expectations for the role of the police. Police generally adopt a crime control approach in their investigative processes while courts tend to use a due process approach in trials. The article examines the factors within law enforcement, as well as broader societal elements, which lead to police adopting a crime control approach. Also examined are behavioural and situational elements that influence police officers' decisions, particularly when they work from a presumption of guilt. This approach often conflicts with the legal presumption of innocent until proven guilty that is required in the trial process. This creates tensions, especially when police are required to explain their decisions and actions in the course of a trial. The article argues that the lack of clarity in the laws of police authority has resulted in police officers defaulting to a crime control approach, since it matches their view of their role in society. It conflicts, however, with the courts' assumptions of what police behaviour should be, which leads to tension between the two institutions.
Cet article examine l'interaction et la tension entre l'attitude de la police et celle des tribunaux dans le contexte de la justice criminelle. Il semblerait que les lois canadiennes régissant l'autorité de la police soient généralement permissives, mais qu'il leur manque une définition claire et précise. En conséquence, l'application de ces lois peut être très subjective, causant des problèmes lorsque la police et les tribunaux ont des attentes différentes sur le rôle de la police. Habituellement la police a une approche de répression du crime dans ses enquêtes alors que les tribunaux s'en tiennent plutôt à l'application de la loi dans les procès. $L$ 'article examine les facteurs, au sein de la police, en plus d'éléments sociétaux plus importants, qui mènent la police à avoir une approche de répression du crime. L'article couvre aussi les éléments comportementaux et situationnels influençant les décisions des agents de la police, tout particulièrement lorsque ceux-ci travaillent à partir de l'hypothèse de la présomption de culpabilité. Cette approche est souvent contradictoire avec la présomption juridique d'innocence jusqu'à preuve du contraire qui est nécessaire dans le cas d'un procès. Cette situation crée des tensions, surtout lorsque la police doit expliquer ses décisions et ses actions lors du procès. L'auteur fait remarquer qu'en raison de l'absence de clarté dans les lois régissant les autorités policières, les agents de la police adoptent par défaut une approche de répression du crime, parce que celleci correspond à la vision de leur rôle dans la société. Cette approche est cependant contraire à l'attente des tribunaux quant au comportement de la police, d'où les tensions entre les deux institutions.

\section{TABLE OF ConTEnTS}

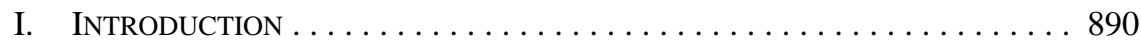

II. Authorities . . . . . . . . . . . . . . . . . . . . . 891

III. Crime Control / Due Process Perspectives . . . . . . . . . . . . . . 893

A. Crime Control vs. Due Process . . . . . . . . . . . . . . . . 894

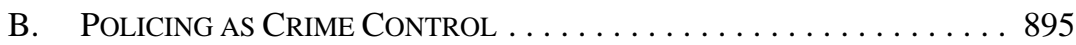

C. ORganizATIONAL FACTORS $\ldots \ldots \ldots \ldots \ldots \ldots \ldots \ldots \ldots \ldots \ldots \ldots \ldots$

D. OPERATIONAL FACTORS $\ldots \ldots \ldots \ldots \ldots \ldots \ldots \ldots \ldots \ldots$

BSc, LLM (Osgoode Hall). I have been a police officer with the Royal Canadian Mounted Police for 13 years. This article was previously submitted to Professor James Stribopoulos as part of my LLM degree requirements and I thank him and Adam Ryder for their helpful comments on an earlier draft. Of course, any errors remain my own. The views expressed here are solely my own and do not represent the views of the Government of Canada or the RCMP. 
E. Cultural Factors $\ldots \ldots \ldots \ldots \ldots \ldots . \ldots \ldots . \ldots \ldots$

F. Differentiating the Police AND the CROWN . . . . . . . . . . . 898

IV. Competitive Policing . . . . . . . . . . . . . . . . . . . . . . . . . . . 899

A. Policing as Crime-Fighting $\ldots \ldots \ldots \ldots \ldots \ldots \ldots \ldots$

B. SOCIAL ISOLATION FROM CONVENTIONAL CITIZENRY $\ldots \ldots \ldots$. . . 901

C. AUTHORITY . . . . . . . . . . . . . . . . . . . . . . . . . 901

D. DANGER AND HYPERVIGILANCE $\ldots \ldots \ldots \ldots$. . . . . . . . . . . . . 902

E. Cynicism AND the Police World View . . . . . . . . . . . . . . . . . . . . . . . . . . . . . . .

F. IMPLICATIONS OF SOCIAL ISOLATION $\ldots \ldots \ldots \ldots \ldots$. . . . . . . . . 904

G. CRIMINALS AND POLICE OFFICERS

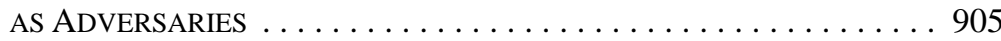

H. POLICING AND MORALITY . . . . . . . . . . . . . . . . . . . . . . 907

I. THE USE OF FORCE . . . . . . . . . . . . . . . . . . . . . . . . . . . . 909

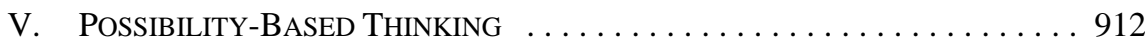

A. INVESTIGATIVE NECESSITY . . . . . . . . . . . . . . . . . . . 913

B. OfFICER SAFETY . . . . . . . . . . . . . . . . . . . . . . 915

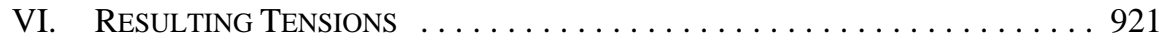

VII. CONCLUSION .......................... 926

\section{INTRODUCTION}

The criminal process has been described "but only partially and inadequately, by referring to the rules of law that govern the apprehension, screening, and trial of persons suspected of crime." ${ }^{1}$ That apt description illustrates a fascinating intersection between the "wide range of activities and actors which respond to crime." ${ }^{2}$ This article seeks to further understand that intersection and to explain the frequent disconnect between what the law demands, what the police do, and what the courts expect.

This article argues that this disconnect is not attributable to the laws that govern police authority; these actually create a permissive environment for police operations. Rather, it is due to the realities of police work and a resulting fundamental difference in the manner that the police and the courts view the role of the police. The main objective of this article will be to gain an understanding of half of that equation; the factors which affect the "cognitive lenses" 3 through which the police view their role in the criminal process. While not an attempt to re-define a general "working personality" 4 of police officers — if one even exists ${ }^{5}$ — the argument herein will nonetheless draw upon behavioural and situational factors unique to the social and practical situation of policing that can influence police officer decisions. This article therefore seeks to build on the “[a]nalysis of the policeman's cognitive propensities [which] is necessary to understand the practical dilemma faced by police required to maintain

Herbert L Packer, “Two Models of the Criminal Process” (1964) 113:1 U Pa L Rev 1 at 2.

Kent Roach, Due Process and Victims' Rights: The New Law and Politics of Criminal Justice (Toronto: University of Toronto Press, 1999) at 11.

Jerome H Skolnick, Justice Without Trial: Law Enforcement in Democratic Society, 2nd ed (New York: John Wiley \& Sons, 1975) at 42.

Ibid.

See generally Robert W Balch, “The Police Personality: Fact or Fiction?” (1972) 63:1 J Criminal L Criminology \& Police Science 106. 
order under a democratic rule of law." ${ }^{6}$ In doing so, the article aims to contribute to the understanding of "the substantial divide between the law's formal demands and the actual workings of the criminal process."7

Part II will briefly explore some of the most common police authorities, which will provide a starting point for our analysis. Part III will discuss the perspective from which the police interpret those authorities and view their role in the criminal process, utilizing the crime control and due process models. Parts IV and V will explore the factors that predominately define the cognitive lens of the police, those being a view of policing as a competitive endeavour and engaging in possibility-based thinking. Part VI will discuss in greater detail how these factors result in tensions between the courts and the police.

\section{Authorities}

Canadian laws do not present insurmountable obstacles that prevent police officers from fulfilling their principal duties of the preserving the peace, preventing crime, and protecting life and property. ${ }^{8}$ Indeed, the police are afforded "broad and far reaching powers including those of search, seizure, arrest and the right to bear arms." ${ }^{9}$ Legislation and common law authorities enable police officers to take investigative action, and in some cases compel compliance, including through the use of physical force, upon satisfying surprisingly low thresholds of belief. These authorities exist across the spectrum of permissiveness, from allowing the arbitrary exercise of police power to requiring that an officer possess some minimum threshold of belief, typically reasonable suspicion or reasonable grounds to believe.

Perhaps the most permissive authority stems from the ancillary powers doctrine otherwise known as the Waterfield test - which enables "the police to perform such reasonable acts as are necessary for the due execution of their duties."10 This common law authority allows for a varying impact on freedoms and privacy provided that the police conduct "falls within the general scope of any duty imposed by statute or recognised at common law" 11 and does not involve "an unjustifiable use of powers."12

The ancillary powers doctrine is the authority by which the police can lawfully conduct random motor vehicle stops and roadblocks to detect impaired drivers, even in the absence of any sort of suspicious driving. ${ }^{13}$ It is the also the authority by which police officers responding to 911 calls can enter a private residence without warrant to ensure the

Skolnick, supra note 3 at 43.

James Stribopoulos, “Packer's Blind Spot: Low Visibility Encounters and the Limits of Due Process versus Crime Control” in François Tanguay-Renaud \& James Stribopoulos, eds, Rethinking Criminal Law Theory: New Canadian Perspectives in the Philosophy of Domestic, Transnational, and International Criminal Law (Oxford: Hart, 2012) 193 at 196 [Stribopoulos, "Packer’s Blind Spot”].

8 Dedman $v$ The Queen, [1985] 2 SCR 2 at 32 [Dedman].

9 Manitoba, The Inquiry Regarding Thomas Sophonow: The Investigation, Prosecution, and Consideration of Entitlement to Compensation (Winnipeg: Manitoba Justice, 2001) (Commissioner Hon Peter deC Cory), online: <digitalcollection.gov.mb.ca/awweb/pdfopener?smd=1\&did=12713\&md=1> [Sophonow Inquiry].

$10 \quad R v$ Waterfield, [1963] 3 All ER 659 (CCA) [Waterfield]; LH Leigh, Police Powers in England and Wales (London: Butterworths, 1975) at 33.

Waterfield, ibid at 661 .

Ibid.

Dedman, supra note 8. 
occupants' safety, even in cases where the 911 call was disconnected before any distress could be established. ${ }^{14}$ When necessary during the investigation of a specific criminal offence, the doctrine allows police to temporarily detain suspects and frisk them for weapons based on a standard of reasonable suspicion. ${ }^{15}$ Depending on the severity of the crime, detention can even occur absent individualized suspicion establishing a clear nexus between the suspect detained and the offence under investigation. ${ }^{16}$

An analysis of legislated investigative authorities shows a similarly wide spectrum of lawful police action. Again, that spectrum begins at the arbitrary exercise of authority. For example, provincial legislation allows for the random stopping of motor vehicles to ensure the driver is licenced and the vehicle registered, even in the absence of any reasons to suspect otherwise. ${ }^{17}$ Such random stops, though arbitrary, do not offend the Charter ${ }^{18}$ due to the overriding public interest in highway safety and the privileged nature of driving. ${ }^{19}$

Most legislated authorities, however, require the officer to possess a threshold of belief ranging from reasonable suspicion to reasonable grounds to believe. For example, police can obtain a warrant to install a tracking device on a person's vehicle ${ }^{20}$ or a number recorder on their phone ${ }^{21}$ upon satisfying a justice that there are reasonable grounds to suspect that an offence has been or will be committed and that relevant information pertaining to that offence will be obtained through the use of the device.

It is when the police are able to satisfy the reasonable grounds to believe threshold that their ability to take lawful action is truly enabled. Although not an exhaustive list, an officer so armed may arrest a person without warrant, ${ }^{22}$ obtain a warrant to search a home, ${ }^{23}$ compel a third party to produce documents, ${ }^{24}$ take DNA samples ${ }^{25}$ or bodily impressions ${ }^{26}$ from a suspect, or "use any device or investigative technique or procedure or do any thing described in the warrant that would, if not authorized, constitute an unreasonable search or seizure in respect of a person or a person's property," ${ }^{27}$ provided certain other requirements of the relevant sections are met.

The permissiveness of these authorities is brought into sharper focus when one considers just how low these thresholds of belief are. Even the highest threshold required, reasonable

$R v$ Godoy, [1999] 1 SCR 311 at para 23.

$R v$ Mann, 2004 SCC 52, [2004] 3 SCR 59 [Mann]; $R v$ Kang-Brown, 2008 SCC 18, [2008] 1 SCR 456. [Kang-Brown]; $R$ v Aucoin, 2012 SCC 66, [2012] 3 SCR 408.

$R v$ Clayton, 2007 SCC 32, [2007] 2 SCR 725; $R$ v Murray (1999), 136 CCC (3d) 197 (Qc CA).

Highway Traffic Act, RSO 1990, c H.8, s 216(1).

Canadian Charter of Rights and Freedoms, Part I of the Constitution Act, 1982, being Schedule B to the Canada Act 1982 (UK), 1982, c 11 [Charter].

$R v$ Ladouceur, [1990] 1 SCR 1257; $R$ v Hufsky, [1988] 1 SCR 621 at 636-37.

Criminal Code, RSC 1985, c C-46, s 492.1.

Ibid, s 492.2 .

Ibid, s 495.

Ibid, s 487.

Ibid, s 487.012.

Ibid, s 487.05 .

Ibid, s 487.092.

Ibid, s 487.01 . 
grounds to believe, is less than proof on the balance of probabilities. ${ }^{28}$ Reasonable suspicion, though being more than mere suspicion, is a lower threshold still. ${ }^{29}$

Not only do the police have access to a wide range of authorities that can be engaged at relatively low thresholds of belief, they are also able to use as much force as is reasonably necessary to accomplish their task. ${ }^{30}$ Further, the Charter does not unduly restrict how the police exercise these authorities, essentially only requiring that the police avoid executing their duties in an unreasonable $e^{31}$ or arbitrary ${ }^{32}$ way. The courts have recognized that the police ought to be afforded at least some deference, finding that "[a] certain amount of latitude is permitted to police officers who are under a duty to act and must often react in difficult and exigent circumstances." ${ }^{\text {"G }}$ Generally, the police "should not be criticized unduly for making immediate decisions in the course of duty which, when analyzed with exquisite precision after the event, may not be demonstrated to have been the most appropriate decisions to have made.”34 Simply put, “[p]olice actions should not be judged against a standard of perfection." 35

Certainly, the laws governing police authority in Canada are permissive; what they are not is "clear, prospective and comprehensive." ${ }^{36}$ The ancillary powers doctrine in particular has been criticized as "a fact-specific ex post facto inquiry that is vague and speculative."37 Though formulated in a more prospective manner, legislated authorities require justification based on thresholds of belief expressed as "requisite degrees of probability [which] have generally been accepted by the courts as incapable of precise definition." 38 Police powers are highly subjective and therefore the cognitive lens through which these powers are interpreted becomes relevant to our inquiry.

\section{Crime Control / Due Process Perspectives}

In attempting to understand the perspective from which the police interpret their authorities, we must first look at how the police and the courts view not only the purpose of the criminal process as a whole, but also what role the police should play in that process. For that purpose, it is helpful to adopt the relatively simple yet "dominant theoretical account of the criminal process" ${ }^{39}$ provided by Herbert Packer. Packer described the criminal process

Mugesera v Canada (Minister of Citizenship and Immigration), 2005 SCC 40, [2005] 2 SCR 100 at para 114 [Mugesera].

Kang-Brown, supra note 15; $R v$ Chehil, 2013 SCC 49, [2013] 3 SCR 220 at para 27.

Criminal Code, supra note 20, s 25(1).

Charter, supra note 18, s 8.

Ibid, s 9 .

$R v$ Asante-Mensah, 2003 SCC 38, [2003] 2 SCR 3 at para 73.

Besse v Thom (1979), 96 DLR (3d) 657 (BC Co Ct) at 667.

$R v$ Nasogaluak, 2010 SCC 6, [2010] 1 SCR 206 at para 35 [Nasogaluak].

James Stribopoulos, "The Limits of Judicially Created Police Powers: Investigative Detention after Mann" (2007) 52:3 Crim LQ 299 at 326 [Stribopoulos, "Investigative Detention"].

37 Don Stuart, "Charter Standards for Investigative Powers: Have the Courts Got the Balance Right?" in Jamie Cameron \& James Stribopoulos, eds, The Charter and Criminal Justice: Twenty-Five Years Later (Markham: LexisNexis, 2008) 3 at 12.

Justice Casey Hill, “Investigative Detention: A Search/Seizure by Any Other Name?” in Cameron \& Stribopoulos, ibid, 179 at 185.

Stribopoulos, "Packer’s Blind Spot,” supra note 7 at 193. 
as a system under tension between "two separate value systems that compete for attention."40 Packer labeled these value systems the crime control model and the due process model.

It is argued that police officers predominately subscribe to the crime control model. This can be juxtaposed against the court environment - which better fits within the due process model - which the officer is later forced to interact with and where any exercise of authority will be thoroughly examined. This is not to assert that the role of any participant in the criminal process - or the criminal process itself as it currently exists in Canada — can be solely placed in one camp or the other. However, just as the two models are useful to describe "the operation of a process whose day-to-day functioning involves a constant series of minute adjustments between the competing demands of two value systems," ${ }^{41}$ so too are they helpful to describe the source of tension between the courts and the police.

\section{A. Crime Control vs Due Process}

The crime control model "is based on the proposition that the repression of criminal conduct is by far the most important function to be performed by the criminal process." ${ }^{22}$ Effective repression, the model holds, requires the primacy of efficiency, that being "the system's capacity to apprehend, try, convict, and dispose of a high proportion of criminal offenders whose offenses become known."43 Successful application of the crime control model determines the probable guilt of a person in the earliest possible stage and secures a conviction in the most expeditious manner possible. ${ }^{44}$

To achieve such efficiency, the crime control model requires that a high degree of trust be placed in the abilities of the police to discern who is probably guilty. This requires that as few restrictions as possible be placed on police investigations, with the only acceptable restrictions being those that enhance the reliability of the investigative results. ${ }^{45}$ Since " $[t] h e$ search for truth should take precedence over concerns about the manner in which evidence was acquired," ${ }^{46}$ reliable evidence should always be admissible.

The due process model, on the other hand, questions the ability of the police and prosecutors to reliably discern guilt through investigative and screening processes. Thus, there is a need for "formal, adjudicative, adversary factfinding processes in which the factual case against the accused is publicly heard by an impartial tribunal and is evaluated only after the accused has had a full opportunity to discredit the case against him."47 In this way, the due process model seeks to prevent and eliminate error to the greatest extent possible. ${ }^{48}$

Packer, supra note 1 at 5 . While Packer's models pertained to the criminal process as a whole, the following analysis will be restricted to how these models can be applied to policing, and only insofar as policing intersects with the rest of the criminal process.

Ibid at 6 .

Ibid at 9 .

Ibid at 10 .

Ibid at 11 .

Ibid at 13 .

Stribopoulos, "Packer's Blind Spot,” supra note 7 at 197.

Packer, supra note 1 at 14.

Ibid at 15. 
The due process model questions the accuracy of police investigations and the manner in which they are conducted, finding them to be "coercive, restricting, and demeaning" 49 and subject to abuse. As such, a reduction of efficiency is acceptable provided it is done with the goal of preventing undue oppression. Finally, in addition to showing the factual guilt of the accused, the focus of the due process model is also to establish the soundness of the procedure followed in acquiring the evidence and trying the allegation. ${ }^{50}$

\title{
B. Policing as Crime Control
}

To confirm whether or not the police subscribe to the crime control model, we need look no further than a brief submitted to the Law Reform Commission (LRC) by the Canadian Association of Chiefs of Police:

\begin{abstract}
The Criminal Justice System does require reform, however the LRC has failed to grasp the essential reform that is needed. Liberalization of homicide laws, decriminalization of property offences, expansion of the possible defences to criminal liability and the codification of inflexible, and indeed debilitating, controls on police investigative techniques are NOT required. What IS required is the streamlining of the pre-trial and court system, the strengthening of sentencing procedures, the recognition of the plight of the victim of crime and the re-introduction into our society of an essential respect for the rule of law and an understanding that it is NOT acceptable to infringe on other people's rights. ${ }^{51}$
\end{abstract}

Of course, further analysis is instructive. That individual police officers, as well as policing organizations as a whole, subscribe to the crime control model is discernible primarily from three factors. Firstly, organizational factors and external metrics of success drive policing agencies to a crime control model interpretation of their role. Secondly, the operational factors governing the job of an individual police officer conducting a criminal investigation demand that the officer operate as an "agent of crime control." 52 Finally, cultural factors that hold policing as a moralistic, competitive endeavour are satisfied by the crime control model and the accompanying presumption of guilt, which serves to identify adversaries for the police.

\section{ORgANizATIONAL FACTORS}

Policing is expensive. In 2011, Canadians spent $\$ 12.9$ billion on police service operating expenditures. ${ }^{53}$ With their allocated funding the police are expected to preserve the peace, prevent crime, and apprehend criminals. ${ }^{54}$ Against constantly growing $\operatorname{costs}^{55}$ there are "increasing calls to demonstrate the value of the investments that all governments make in

Ibid at 16.

Stribopoulos, "Packer's Blind Spot," supra note 7 at 199.

Canadian Association of Chiefs of Police, The Law Reform Commission: A Police Perspective (Toronto: Canadian Law Information Council, 1984) at 3 [emphasis in original].

Stribopoulos, "Packer's Blind Spot," supra note 7 at 200.

Statistics Canada, Police Resources in Canada 2012, prepared by Marta Burczycka, Catalogue No 85225-X (Ottawa: Statistics Canada, March 2013) at 5, online: <statcan.gc.ca/pub/85-225-X/85-225x2012000-eng.pdf> [Police Resources 2012].

$54 \quad$ Royal Canadian Mounted Police Act, RSC 1985, c R-10, s 18 [RCMP Act].

$55 \quad$ Police Resources 2012, supra note 53 at 29, (noting that since 1985, and adjusted for inflation, the per capita cost of policing has risen from $\$ 218$ to \$313). 
... policing." 56 There is certainly nothing wrong with demanding that the police be held accountable for budget expenditures. Indeed, such accountability is crucial to establish legitimacy and ensure adequate performance. ${ }^{57}$ However, the manner in which this is done inevitably pushes policing organizations towards embracing the crime control model.

Police agencies provide a wide range of services beyond their most obvious function of investigating crime and apprehending offenders. That said, while services such as order maintenance and dispute resolution may indeed account for the largest proportion of how police spend their time, the outcomes of duties that fall outside of actual criminal investigations are intangible and difficult to measure. ${ }^{58}$ Thus, "policing performance measures are not well-developed, widely applied, or reported to the public.,59 The lack of "clarity as to the efficiency and effectiveness of police spending" 60 thwarts efforts to report a financial "bottom line"61 showing the return on Canada's investment in policing. Nevertheless, the pressure for police agencies to account for their expenditures is unrelenting. Success thus becomes defined by hard data that can be measured, such as crime and clearance rates. ${ }^{62}$

To be sure, it is crucial for police agencies to possess at least a minimum level of competence in solving crime. There is nothing negative about defining police effectiveness, at least in part, by what proportion of reported crime they solve. However, the use of this metric as the sole manner in which performance is measured has an effect on how a policing organization perceives its purpose. As the inquiry into the wrongful conviction of Guy Paul Morin heard, "[a] police culture that rewards case clearances may dictate police behaviour in the investigation of a case. ${ }^{, 63}$ Professors Innes and Fielding provided a broader explanation:

[P]erformance measures are profoundly political instruments, functioning both to articulate and animate normative concerns. They articulate by virtue of identifying which services are valued above others and what are to be seen as priorities. Yet they also serve to animate public service delivery, in that they shape organizational priorities and thus order the domains of organizational activity and how practices are performed. $^{64}$

Vic Toews, "Speech by the Honourable Vic Toews, Minister of Public Safety, at the Summit on the Economics of Policing,” (16 January 2013), online: <publicsafety.gc.ca/cnt/nws/spchs/2013/ 20130116eng.aspx> [Toews, "Economics of Policing”].

Mark H Morre \& Anthony A Braga, "Police Performance Measurement: A Normative Framework” (2004) 23:1 Criminal Justice Ethics 3 at 5.

Curt Griffiths \& Simon N Verdun-Jones, Canadian Criminal Justice, 2nd ed (Toronto: Harcourt Brace, 1994) (noting “crime control activities generally occupy less than $25 \%$ of police officers' time, and for most officers, this figure is considerably lower" at 71); Samuel Walker, The Police in America: An Introduction, (New York: McGraw-Hill, 1983) at 58.

Toews, "Economics of Policing," supra note 56.

Ibid.

Morre \& Braga, supra note 57 at 5.

Statistics Canada, "Police-reported clearance rates in Canada, 2010,” by Tina Hotton Mahony \& John Turner, in Juristat, Catalogue No 85-002-X (Ottawa: Statistics Canada, 2012), online: <www.statcan. gc.ca/pub/85-002-x/2012001/article/11647-eng.pdf>.

Ontario, Report of the Kaufman Commission on Proceedings Involving Guy Paul Morin (Toronto: Ontario Ministry of the Attorney General, 1998) vol 2 (Commissioner: Hon Fred Kaufman) at 1095 [Morin Report].

Nigel Fielding \& Martin Innes, "Reassurance Policing, Community Policing and Measuring Police Performance” (2006) 16:2 Policing \& Society 127 at 127. 
The current predominant policing performance metrics - the amount of reported crime and subsequent clearance rates - are direct measurements of police efficiency in only one area of service delivery: formal law enforcement. These measures serve to align policing priorities with those activities that will improve efficiency in that single dimension. This places policing organizational priorities firmly within the crime control model.

\section{OPERATIONAL FACTORS}

The crime control versus due process distinction is brought into the sharpest relief when considered in light of their respective defining characteristics of presumption of guilt versus presumption of innocence. Packer was cautious to point out that the presumption of guilt is not a rule of law, nor the opposite of the presumption of innocence, but rather an exemplification of attitudes. Packer explained the difference between the presumption of guilt and innocence as follows:

\footnotetext{
The presumption of innocence ... is irrelevant to the presumption of guilt; the two concepts embody different rather than opposite ideas.... [The presumption of innocence] means that until there has been an adjudication of guilt by an authority legally competent to make such an adjudication, the suspect is to be treated, for reasons that have nothing whatever to do with the probable outcome of the case, as if his guilt is an open question.
}

The presumption of innocence is a direction to officials how they are to proceed, not a prediction of outcome. The presumption of guilt, however, is basically a prediction of outcome. The presumption of innocence is really a direction to the authorities to ignore the presumption of guilt in their treatment of the suspect. It tells them, in effect, to close their eyes to what will frequently seem to be factual probabilities. The reasons why it tells them that are among the animating presuppositions of the Due Process Model.... [T] he presumption of guilt is descriptive and factual; the presumption of innocence is normative and legal. ${ }^{65}$

Operational realities of policing require a presumption of guilt. The police investigate and solve crime. Beyond their legislated duty to do so, it is also the primary means by which their success is defined, as discussed above. ${ }^{66}$ Thus, while the police are (or should be) a disinterested party vis-à-vis who gets charged with a crime, they very much have a stake in if someone gets charged with a crime. Solving a crime requires the officer, at some point, to vector in on a suspect and make efforts to collect evidence of that suspect's guilt. In order to bring an investigation to a successful conclusion, the police must adopt a presumption of guilt towards a specific person. This marries up with the basic tenets of the crime control model, which allow for, if not require, sufficient trust to be placed in the investigative process such that once a suspect has been investigated and not found to be probably innocent, then "all subsequent activity directed toward him is based on the view that he is probably guilty."67

The vectoring in on a specific suspect will usually result in the police using some sort of lawful authority to further their investigation. At this point, the criminal process actually

$65 \quad$ Packer, supra note 1 at 12.

66 RCMP Act, supra note 54, s 18(a); Police Services Act, RSO 1990, c P.15, s 42(1)(d).

Packer, supra note 1 at 11 . 
demands that the police act based on a presumption of guilt. For example, prior to making an arrest, the officer must personally believe the suspect has committed the crime for which the arrest is being made. ${ }^{68}$ While this belief must be based on objectively discernible facts, it must also rest on a foundation of the officer's subjective belief. ${ }^{69}$ Similarly, prior to obtaining a search warrant, an officer must possess a belief that an offence has been committed and that evidence of that offence exists at a given location. ${ }^{70}$ While the search warrant standard does not require a belief of a given party's guilt, ${ }^{71}$ oftentimes such a belief will be readily implied, if not stated outright, in an information to obtain a search warrant. Of course, this is not particularly upsetting, for few would want the police to be able to take action against persons they thought were innocent. Still, that the police operate under such requirements reinforces a modus operandi of adopting a presumption of guilt.

\section{E. Cultural Factors}

The culture of policing, specifically the view that police officers are "combatants engaged in a competitive endeavour,"72 also pushes officers towards a presumption of guilt, and therefore towards the crime control model. That policing is seen as a competitive endeavour, which shall be explored in greater detail below, has been commented on by many, is frequently sensationalized in the media, and is observable from the behaviour of police themselves. ${ }^{73}$ The most poignant result of this cultural identity is that it requires that the police presume guilt. That is, if policing is viewed as a crime-fighting endeavour, then an enemy is necessary to legitimize the model. ${ }^{74}$ These enemies can only be provided through the presumption of guilt.

\section{F. Differentiating The Police ANd the Crown}

Although the police and prosecutors have both been described as being "agents of crime control," ${ }^{75}$ for the purposes at hand, it can be argued that a distinction could be made between the two. This distinction will not only differentiate the police from the Crown, but also from the rest of the criminal process, and will thus demonstrate the potential for significantly different perspectives.

The roles of the police and prosecutors can be differentiated in a number of ways. First, the authority of the police is confined to the investigative phase of the criminal process whereas the role of the Crown is constrained within the adjudicative phase. This distinction

$68 \quad$ Criminal Code, supra note 20, s 495.

$69 \quad R$ v Storrey, [1990] 1 SCR 241 at 250-51.

Criminal Code, supra note 20, s 487.

That is, a search warrant can be obtained even in the absence of a suspect being identified, as long as the evidence is believed to exist.

72 James Stribopoulos, “Unchecked Power: The Constitutional Regulation of Arrest Reconsidered” (2003) 48:2 McGill LJ 225 at 245 [Stribopoulos, "Unchecked Power”].

73 See generally ibid; Stanley A Cohen, "Invasion of Privacy: Police and Electronic Surveillance in Canada" (1982) 27:4 McGill LJ 619 at 620; Greg Marquis, "Power from the Street: The Canadian Municipal Police” in RC Macleod \& David Schneiderman, eds, Police Powers in Canada: The Evolution and Practice of Authority (Toronto: University of Toronto Press, 1994) 24 ("[a]s far as chief constables were concerned, the police and criminals were in a state of war, a sort of criminological Social Darwinism” at 31).

74 Christopher Braiden, "Policing: From the Belly of the Whale” in Macleod \& Schneiderman, ibid, 309 at 312.

Stribopoulos, “Packer’s Blind Spot,” supra note 7 at 200. 
"allows both the police and Crown counsel to exercise discretion independently and objectively [and] forms part of a system of checks and balances."76 While the realities of the criminal process require "cooperative and effective consultation between the police and the Crown ... the policing function — that of investigation and law enforcement - is distinct from the prosecuting function." ${ }^{\text {,7 }}$ Indeed, the Supreme Court of Canada has held that "Crown objectivity and the separation of Crown from police functions are elements of the judicial process which must be safeguarded." ${ }^{\text {,8 }}$

Second, while it may be true that some prosecutors subscribe to the crime control model and view themselves as partners of the police in the war on crime, the competitive motivations entrenched in policing do not, or ought not, animate the adjudicative portion of the criminal process. Notwithstanding a duty to "vigorously pursue a legitimate result to the best of its ability,"79 it has offended the court when the Crown has presented the jury with personal conclusions, drawn from an investigation, that an accused was guilty. ${ }^{80}$ The need for Crown counsel to eschew the thought of a prosecution as being a struggle for a conviction, or a contest of professional superiority, skill and preeminence ${ }^{81}$ was most famously explained by Justice Rand in R. v. Boucher:

\begin{abstract}
It cannot be over-emphasized that the purpose of a criminal prosecution is not to obtain a conviction, it is to lay before a jury what the Crown considers to be credible evidence relevant to what is alleged to be a crime. Counsel have a duty to see that all available legal proof of the facts is presented: it should be done firmly and pressed to its legitimate strength but it must also be done fairly. The role of prosecutor excludes any notion of winning or losing; his function is a matter of public duty than which in civil life there can be none charged with greater personal responsibility. It is to be efficiently performed with an ingrained sense of the dignity, the seriousness and the justness of judicial proceedings. ${ }^{82}$
\end{abstract}

\title{
IV. Competitive Policing
}

The police, however, are not prevented from adopting competitive sentiments, and policing is often viewed as a competitive endeavour pitting police against criminals in a "war on crime.” This crime-fighting image can be distilled into two contributing factors that are relevant for our purposes. First, it results from the social isolation of the police from both conventional and criminal members of society. Second, it is predicated on a conclusion that policing is not merely an exercise of law, but an expression of morality: a necessary imposition of proper behaviour on the dissolute.

To be sure, us-them competitive thinking is absolutely appropriate in some cases, particularly when dealing with the most dangerous offenders and use of force issues. in Crown Policy Manual (21 March 2005), online: <www.attorneygeneral.jus.gov.on.ca/english/crim/ cpm2005/CPMPreamble.pdf>.

77 Nova Scotia, Royal Commission on the Donald Marshall, Jr., Prosecution: Findings and Recommendations (Halifax: Province of Nova Scotia, 1989) vol 1 (Chair: Hickman CJ) at 232 [Marshall Commission].

$R v$ Regan, 2002 SCC 12, [2002] 1 SCR 297 at para 70 [Regan].

$R v$ Cook, [1997] 1 SCR 1113 at para 21.

Regan, supra note 78 at para 65 discussing Boucher v The Queen (1954), [1955] SCR 16 [Boucher].

Boucher, ibid at 25, citing $R$ v Ruddick (1865), 4 F \& F 497 at 499.

Boucher, ibid at 23-24. 
Adopting an us-them perspective may also be a useful tool for police officers to insulate themselves from the emotional impact of a career of witnessing human trauma. However, by overly identifying with a view that policing is a war on crime, officers risk losing perspective of their wider function as peace officers and their subservience to the rule of law.

\section{A. Policing as Crime-Fighting}

The idea that police and criminals are engaged "in a state of war, a sort of criminological Social Darwinism," ${ }^{83}$ provides a highly romanticized construct of policing. Stanley Cohen put it aptly:

Crime fighting is in many ways the most attractive aspect of police work and it is from this work that the police have derived their most positive public (and self) image. Crime fighting is in colloquial terms the “cops and robbers” aspect of police work. It involves the investigation of crime - the pursuit and apprehension of criminals... It is the view of most modern policemen that "catching criminals, especially the violent and the organized,... constitutes the real core of the job.”84

This crime-fighting image has been actively perpetuated by the entertainment and news media, which take advantage of the powerful grip the image exerts on the public imagination. ${ }^{85}$ Police dramas overemphasize violence and action when police are solving crime ${ }^{86}$ Further, clearance rates are exaggerated and "[c]rime is often shown as being both random and the result of individual pathology rather than larger social ills such as poverty, racism and unemployment." ${ }^{\text {"7 }}$ These dramatizations support the crime-fighting image of police officers engaged in a competitive endeavour against individual offenders with the more complicated issues surrounding crime being conveniently ignored.

The police themselves also subscribe to the crime-fighting image. As discussed above, the success of the police is largely defined by clearance rates of criminal offences, a direct measure of their crime-fighting abilities. That the police adopt " $t$ t]he concept of a profession [which] includes the idea of an important mission" ${ }^{\text {" }}$ is discernible by a popular analogy within the police subculture of being society's "sheepdogs." 89 This analogy, which is so frequently referenced in policing circles that it has become somewhat cliché, is worth exploring in some detail..$^{90}$

In the sheepdog analogy, society is divided into three groups. The law-abiding citizen, being a peaceful and productive person who is incapable of violence except under extreme provocation, is a sheep. This characterization is meant to be descriptive, not derogatory, as

$83 \quad$ Marquis, supra note 73 at 31.

Cohen, supra note 73 at 620 [footnotes omitted].

Walker, supra note 58 at 54.

John H Culver \& Kenton L Knight, “Evaluating TV Impressions of Law-Enforcement Roles” in Ralph Baker \& Fred A Meyer Jr, eds, Evaluating Alternative Law-Enforcement Policies (Lexington: Lexington Books, 1979) 201 at 207.

87 Sarah Eschholz, “Crime on Television — Issues in Criminal Justice” (2003) 2 J Institute Justice \& Intl Studies 9 at 11 [footnotes omitted].

Walker, supra note 58 at 55 [emphasis in original].

Dave Grossman, On Combat: The Psychology and Physiology of Deadly Conflict in War and in Peace, 2nd ed (Millstadt: Warrior Science Publications, 2007) at 180 [Grossman, On Combat].

T-shirts, patches, and other insignia bearing the word "sheepdog" are sold in many police supply stores. 
the average citizen in our society avoids conflict and has little capacity for, or exposure to, interpersonal violence. They are productive members of society who naturally expect others to be as well. There are, however, evil-doers in the world who have a capacity for violence and who prey on the sheep. These criminals are the wolves. Finally, soldiers and police officers, those who are capable of violence but who are guided by a morality that the wolves lack, are the sheepdogs, tasked with protecting the flock. ${ }^{91}$

This analogy of policing paints the police officer as being in perpetual combat against the forces of evil; us against them. It incorporates an obligation for the sheepdogs to only use their capacity for violence - their "gift for aggression"92 — to protect society. Dave Grossman described this mission by quoting the motto of one California law enforcement agency — "We intimidate those who intimidate others" — thereby advancing a simultaneously combative and paternalistic relationship between the police and society. ${ }^{93}$

\section{B. SOCIAL ISOLATION FROM CONVENTIONAL CITIZENRY}

The us-them policing model is useful because, to a large extent, it is accurate. Putting aside the combative view of police against criminals for a moment, it has been wellestablished that police officers are, in fact, socially isolated from conventional society. ${ }^{94}$ This is due to a combination of the elements of authority and danger present in the police officer's work and the cynical world view that results from a career in policing. ${ }^{95}$

\section{AUTHORITY}

Members of the public have little interaction with the police and even then usually only in routine situations. Despite this, many people have a fascination with policing and, just as the police officer often over-identifies with his work role when defining his sense of self, members of the public over-emphasize a police officer's work as the defining characteristic of who the police officer is. ${ }^{96}$ That is, even in off-duty, social situations, the police officer's job as a "cop" is what defines him as a person in the eyes of the people he is trying to socialize with, hampering normal relationships. The general public fails to recognize that "[p]olicemen may simply be very ordinary people who happen to be extraordinarily visible." ${ }^{97}$ Every police officer has had the experience of meeting someone for the first time, disclosing their occupation, and then having to suffer through complaints about undeserved

Grossman, On Combat, supra note 89 at 180-81.

Ibid at 181.

Ibid. While the motto "We intimidate those who intimidate others" evokes admirable images of brave officers engaging dangerous gang members to protect innocent victims, it was a motto taken too far. What Grossman fails to point out is that this motto was that of the Los Angeles Police Department Rampart Division CRASH (Community Resources Against Street Hoodlums) unit — an elite anti-gang unit that was ultimately disbanded after allegations of assaults, theft of drugs, and framing of suspects. Whether the CRASH unit succumbed to pervasive corruption or merely isolated incidents of misconduct by certain officers is not conclusively clear, but it nonetheless forms a cautionary tale. For a more complete story see Peter J Boyer, "Bad Cops," The New Yorker (21 May 2001), online: <www.new yorker.com/magazine/2001/05/21/bad-cops>.

See generally, Bruce Swanton, "Social Isolation of Police: Structural Determinants and Remedies" (1981) 3:4 Police Studies Intl Rev Police Development 14.

Skolnick, supra note 3 at 44.

See generally Kevin M Gilmartin, Emotional Survival For Law Enforcement: A Guide for Officers and Their Families (Tucson: E-S Press, 2002).

Balch, supra note 5 at 117. 
traffic tickets or, at best, having to respond to legitimate interest in policing "war stories" which the officer probably has limited interest in recounting. Indeed, "the whole civilian world is an audience for the policeman [which] further promotes police isolation and, in consequence, solidarity."98

Jerome Skolnick concluded that this social isolation arises from the authority possessed by the officer, and is predominately due to potential hypocrisy from the officer using said authority to enforce laws representing "puritanical morality" that the officer himself does not subscribe to. ${ }^{99}$ However, it can be argued that it is the coercive authority possessed by a police officer that accounts for this isolation. Egon Bittner's position was that the capacity to use force is the defining characteristic of the police officer's on-duty role. ${ }^{100}$ This can be extended, as the element of coercive authority possessed by a police officer continues to define the officer even in off-duty situations. Even though the completely law-abiding citizen would never be the subject of the exercise of coercive police authority, the potential that it could be used in some hypothetical circumstance serves as a barrier to a normal friendship between a police officer and a civilian. Further, the law-abiding citizen who nonetheless dislikes or distrusts authority may apply this resentment to any interactions with even an offduty police officer. To avoid these issues, the officer merely avoids socializing with civilians or refrains from disclosing their occupations in social situations.

\section{DANGER AND HYPERVIGILANCE}

Skolnick also argued that the element of danger present in policing further isolates police officers from society. ${ }^{101}$ Kevin Gilmartin concluded that this danger-induced social isolation was a result of an officer's hypervigilance. ${ }^{102}$ Hypervigilance, and its effect on police officers, is worth exploring in some detail as it comes into play not only in regards to social isolation, but also in possibility-based thinking that will be discussed below.

Hypervigilance is a "perceptual set of elevated alertness of the surroundings, which is required of law enforcement officers for survival." 103 Viewing the world through a "threatbased perspective" and adopting a mindset of seeing unfolding events as potential hazards is a necessary skill for police officers who are "exposed every day to a series of unknown events, any one of which could be perfectly harmless or lethally dangerous.”"104

Gilmartin explained that a police officer's state of hypervigilance can best be compared to the feeling that a normal citizen would get when walking on a dark, deserted street. Is the person approaching a potential assailant? Is someone following? The citizen begins to assess all circumstances from a view of what risk they might pose. The general public encounters situations requiring such a mindset infrequently, and only when they cannot be avoided. For

Skolnick, supra note 3 at 44 .

Ibid.

Egon Bittner, The Functions of the Police in Modern Society: A Review of Background Factors, Current Practices, and Possible Role Models (Chevy Chase: National Institute of Mental Health, 1970) at 40. Skolnick, supra note 3 ("the policeman is generally a 'suspicious' person.... Accordingly, the element of danger isolates the policeman socially from that segment of the citizenry which he regards as symbolically dangerous and also from the conventional citizenry with whom he identifies” at 44). Gilmartin, supra note 96 at 35.

Ibid.

Ibid at 34. 
the most part, the average citizen goes about their lives within a normal range of risk such that there is simply no need to engage in excessive contemplation of potential threats. The police, on the other hand, embrace this state of hypervigilance as a necessity to ensure officer safety, and apply it for the majority of their work functions. ${ }^{105}$

According to Gilmartin, police hypervigilance contributes to social isolation as follows. First, officer safety practices meant to address potential threats — such as asking a person to take their hands out of their pockets, or shining a spotlight into a car to illuminate and possibly blind its occupants - may appear to an average citizen, who assesses the action from a perspective of the normal range of risk, as being rude, unnecessary, and perhaps overly coercive. ${ }^{106}$ The difference between how the citizen sees the world from a perspective of normal risk, and how the police officer sees the world from a perspective of elevated yet unquantifiable risk, results in difficulty for police officers to relate with non-police friends and vice-versa. Friendships are also hampered by police officers feeling contempt and jealousy towards civilians: contempt at the ignorance of the civilians who know nothing about the actual threat of physical harm in existence in the world, and jealousy of that undisturbed innocence.

The second way that hypervigilance contributes to social isolation is due to the biological and psychological effects it has on officers. Hypervigilance provides a sense of "alertness, aliveness, and quick decision making." ${ }^{107}$ This heightened alertness has a recreational feel to it, which becomes inseparable from the police role. However, the on-duty feelings of alertness and high energy give way to feelings of fatigue and apathy when off duty. Such is the crash after the high of hypervigilance.

For soldiers in combat, this crash "occurs as soon as the danger and the excitement is over, and it takes the form of an incredibly powerful weariness and sleepiness on the part of the soldier."108 For a police officer, the crash occurs after their shift and officers will socially withdraw from seemingly mundane activities (that is to say those that exist within the normal range of risk) such as interaction with their families and non-police socialization. ${ }^{109}$ It takes 18 to 24 hours to recover from this crash, at which time the officer usually goes back to work, thus creating what Gilmartin calls "the hypervigilance rollercoaster."110 Over the long term, persistent withdrawal from the non-police aspects of an officer's life leads to the officer's sense of self becoming defined solely by his role as a police officer. Such one dimensionality is not emotionally nor socially well-balanced. ${ }^{111}$

It is difficult to fault police officers for wanting to reduce (as much as possible) the potential threats they face. However, risk can never be reduced to zero, and surely some would argue that there comes a point when no matter how good the intentions of hypervigilance, it nonetheless requires coercive practices that the police should not be able to

\footnotetext{
$105 \quad$ Ibid at 37-38.

$106 \quad$ Ibid at 41.

$107 \quad$ Ibid at 42

108 Dave Grossman, On Killing: The Psychological Cost of Learning to Kill in War and Society, revised ed (New York: Back Bay Books, 2009) at 69 [Grossman, On Killing].

Gilmartin, supra note 96 at 59.

Ibid at 47.

Ibid at 73-75.
} 
apply absent some objectively discernible risk factors. How the balance between officer safety and avoidance of coercive policing ought to be achieved is unclear, but regardless, the practice of hypervigilance comes with a cost.

\section{E. Cynicism ANd The Police World VieW}

A final contributor to the social isolation of police officers is a result of the police world view based on cynicism. Police officers, through their constant exposure to negative events and their necessary practice of hypervigilance (which is predicated on a basic distrust of human nature), form a cynical world view. ${ }^{112}$ Of course, this world view does not match that of the conventional citizenry who, for the most part, have limited exposure to the human depravity witnessed daily by police. Indeed, just as the world view of a police officer is overly cynical, the world view of a citizen untouched by crime or violence is likely to be unrealistically innocent. This disconnect can make it difficult for the police to relate to the public, who may be seen as naive (which they may well be), or even cowardly for not being willing to risk their own safety as the officer does. On the other hand, the officer may be viewed as paranoid and unnecessarily aggressive.

\section{F. IMPLICATIONS OF SOCIAL ISOLATION}

We see, then, that the sheepdog analogy is, to some extent, an accurate reflection of reality. The conventional citizenry lives with few concerns about their safety and are free to go about their business. The police, on the other hand, live in a world of unknown and unquantifiable risk that demands constant vigilance. The police and the non-police have completely different world views, and neither understands the other. Grossman explains their interactions as follows:

The sheep generally do not like the sheepdog. He looks a lot like the wolf. He has fangs and the capacity for violence ... [;] the sheepdog disturbs the sheep. He is a constant reminder that there are wolves in the land.... The sheep would much rather have the sheepdog cash in his fangs, spray paint himself white, and go, "Baa.”

Until the wolf shows up. Then the entire flock tries desperately to hide behind one lonely sheepdog.

[A] sheepdog is a funny critter: He is always sniffing around out on the perimeter, checking the breeze, barking at things that go bump in the night, and yearning for a righteous battle....

Here is how the sheep and the sheepdog think differently. The sheep pretend the wolf will never come, but the sheepdog lives for that day. ${ }^{113}$

One implication of this social isolation is that it can become difficult for the police to discern what the expectations of society and the courts are. Since the police are subject to incestuous social confirmation of their attitudes and beliefs by their limited peer group, any 
disagreement between what the police think is appropriate and what the public expects can be written off as a failure of the public to know "how the world really is." Essentially, "officers can lose the capacity to read nuance in the social landscape or even to cast a critical eye on their own behavior." ${ }^{114}$ Objections from the public can be dismissed as bleating of the sheep.

Similarly, findings of the court that do not conform to the police view of what is necessary and appropriate can be viewed as armchair quarterbacking from within the safe confines of a courtroom by those who cannot possibly appreciate what it is like "on the streets." Certainly the courts should not reject the officer's unique perspective of reality, as there is real value to be found there. However, when operations are chastised by the court, the police should be cautious not to embrace the sentiments expressed by Marine Colonel Jessop in the film A Few Good Men (best read in a Jack Nicholson voice): "I have neither the time nor the inclination to explain myself to a man who rises and sleeps under the blanket of the very freedom that I provide, and then questions the manner in which I provide it."115

\section{G. Criminals ANd Police OfFicers as Adversaries}

The above is not to suggest that the sheepdog identity is without merit. If we reject the image of police as crime fighters because that is not their primary function then we risk forgetting that the police are, the ones society calls upon to confront human aggression. ${ }^{116}$ The relative infrequency of such violent encounters does not eliminate the need for an effective model to understand and prepare for such scenarios. Indeed, it is the potential of having to confront human aggression, and the uncertainty of when it will have to be confronted, which creates the necessity of a combative view of policing.

Through exposure to violent incidents the police are conscious of legitimate risks that the average citizen is, for the most part, unaware of. Hypervigilance is not practiced on a whim; it is borne out of hard won experience. Hence, the police perspective should not be dismissed as paranoia. For a warning on the harm of completely rejecting a combatant view of policing, we can return to the wolves and the sheep, but this time in the words of Aesop:

\footnotetext{
"Why should there always be this fear and slaughter between us?” said the Wolves to the Sheep. “Those evildisposed Dogs have much to answer for. They always bark whenever we approach you and attack us before we have done any harm. If you would only dismiss them from your heels, there might soon be treaties of peace and reconciliation between us.” The Sheep, poor silly creatures! were easily beguiled and dismissed the Dogs, whereupon the Wolves destroyed the unguarded flock at their own pleasure. ${ }^{117}$
}

This indeed brings us back to the wolves — the criminals of society — and an analysis of the competitive model of policing that places the police in a war against them. The wolves versus sheepdog characterization seems, at first blush, to be a significant if not completely Department” (1996) 30:4 Law \& Soc’y Rev 799 at 813 [Herbert, “Morality”].

115 A Few Good Men, 1992, DVD (Culver City, Cal: Columbia TriStar Home Entertainment, 2001).

116 Richard V Ericson, “The Police as Reproducers of Order” in KRE McCormick \& LA Visano, eds, Understanding Policing (Toronto: Canadian Scholars’ Press, 1992) 163 at 166.

117 Aesop, “The Wolves and the Sheep” in Aesop's Fables, translated by George Flyer Townsend, (Garden City, NY: Doubleday \& Company, 1968) at 77. 
unnecessary exaggeration. Policing, after all, is not an overly hazardous occupation - not even coming close to fishing or logging for on-the-job fatalities. ${ }^{118}$ While the average annual homicide rate for police officers from 1997 to 2011 of 2.6 per $100,000^{119}$ was higher than the 2011 national average of $1.73,{ }^{120}$ it was significantly lower than the homicide rate of some major Canadian cities in 2011 including Winnipeg (5.08), Halifax (4.41), and Edmonton (4.17). ${ }^{121}$ The murder of a Canadian police officer is, thankfully, a rare event. Why then, it may be asked, is it necessary to construct a view of policing that conjures images of police officers forever in the crosshairs of violent criminals?

The necessity is twofold. First, even if the police were to dismiss this combatant notion, dangerous criminals would not. It is well engrained in the criminal ethos that the police are the enemy. Robert Sand provided a glimpse into this ethos through a diary entry he penned as he sat in a jail cell while on trial for the murder of RCMP Constable Dennis Strongquill. ${ }^{122}$ Sand's words - written after he reviewed crime scene photographs that showed the slain officer and also pictures of his brother, Danny — are chilling:

I was looking at this man, on a table. And he had several shotgun wounds, to the side, back, chest, etc. And I started to think, he's just a man, and shouldn't be dead. He had a family and friends, and now he's a body on a table. I realized it's not the man I hated, but the uniform he wore. His flag, colours of war. But seeing him without his uniform I felt bad for the loss of his life.

I flipped to the pics of Dan, and my thoughts changed. Cuz now I felt that the other man is right where he should be. And losses on both sides are always expected, only Dan took my place. And when I looked up the cop car I felt pride, and remembered the battle. I remembered how these enemy soldiers fled in fear and cowardess. I saw how much damaged I'd causes to there unit and smiled, from the knowledge, that the enemy isn't as strong as they want us to believe. But they should beware that the moment they fly there flag, wear there uniform. That there at war and people die in war, everyone has there enemies. ${ }^{123}$

Second, the competitive model is necessary not because of the lack of safety of policing, but rather due to the unpredictability of when it is unsafe. Indeed, of the 133 Canadian police

Statistics Canada, “A job to die for” by Katherine Marshall, in Perspectives on Labour and Income, vol 8, No 2, Catalogue No 75-001-XPE (Ottawa: Statistics Canada, 5 June 1996) at 27, online: <www. statcan.gc.ca/studies-etudes/75-001/archive/199615018481-eng.pdf> (noting that between 1988 and 1993, fishing and trapping had a fatality rate of 113 work-related deaths per 100,000 workers). Statistics Canada, "Homicide in Canada, 2011" by Samuel Perreault, in Juristat, Catalogue No 85-002X,(Ottawa: Statistics Canada, 4 December 2012) at 16, online: <www.statcan.gc.ca/pub/85-002x/2012001/article/ 11738-eng.htm>.

Ibid at 3.

Ibid at 24 .

The murder of Constable Strongquill was an extraordinary demonstration of aggressive violence, even when compared to the murders of other police officers. Strongquill and his partner had pulled Robert Sand, his girlfriend, and his brother, over for a routine traffic violation, not knowing they had been on a crime spree and were driving a stolen truck. Robert Sand opened fire with a shotgun and the police officers fled in their police truck. The Sands gave chase as the officers fled back to their detachment. In the detachment parking lot, Danny Sand rammed the police car, and Robert Sand fired a shotgun repeatedly at Strongquill, who was pinned in the police car. Strongquill was killed. Danny Sand was killed by a police sniper in a later standoff. Robert Sand was convicted of first degree murder. See Mike McIntyre, Nowhere to Run: The Killing of Constable Dennis Strongquill (Winnipeg: Great Plains Publications, 2003). Ibid at 195. 
officers who were murdered between 1961 and 2009, two-thirds of them never drew or fired their firearm, suggesting that attacks on police officers are often unsuspected. ${ }^{124}$ As Skolnick put it, "[l]ike the animals of the experimental psychologist, the policeman finds the threat of random damage more compelling than a predetermined and inevitable punishment." ${ }^{125}$ By encouraging an adversarial assumption, the competitive model provides a useful framework for police officers to guard against these unknown threats. Essentially, it is easier to teach police officers who subscribe to the wolf versus sheepdog model that "[i]t is better to approach a harmless situation prepared for risk than to approach the lethal situation unprepared."126

This is not to suggest that a police officer only has the choice between either adopting an identity of a coiled cobra ready at any moment for a battle to the death or being completely apathetic to the potential danger of his occupation. It is not an all or nothing dichotomy. Rather, those options represent the two furthest ends on a spectrum of attitudes. ${ }^{127}$ A police officer will move along different points of that spectrum depending on the circumstances presented. However, the combative view of policing is necessary to anchor one end of the spectrum.

Before proceeding, a further word must be said about the difference between the dangers of policing and other hazardous occupations such as logging, as this difference contributes greatly to the combatant view of policing. While there are more deaths in other occupational groups, "the police are the only peacetime occupational group with a systematic record of death and injury from gunfire and other weaponry." 128 The crucial difference is that the cause of some fatalities in policing is interpersonal violence. ${ }^{129}$ The risk of death from interpersonal violence causes a higher degree of psychological trauma and alters behaviour in a fundamentally different way than the risk of death from acts of nature, accidents, or natural causes. ${ }^{130}$ The risks inherent in policing, though they do not produce as many deaths as some other occupations, nonetheless motivate a completely different response because of the source of the risk.

\section{H. Policing AND Morality}

Given the dangers of policing, and the traumatic nature of those dangers, one may wonder on what basis people are motivated to become police officers? Certainly the excitement and action have something to do with it, although, to be frank, the actual level of excitement is far less than the media (and police recruiters) make it out to be. While everyone will have different reasons for becoming a police officer, the sense of purpose associated with policing — the idea that policing is a calling and not just a job — is a common refrain from applicants

Statistics Canada,“Police officers murdered in the line of duty, 1961 to 2009," by Sara Dunn, in Juristat, vol 30, No 3, Catalogue No 85-0022-X (Ottawa: Statistics Canada, 2010) at 8 <www.statcan.gc.ca/ pub/85-002-X/201003/article/11354-eng.pdf>.

125 Skolnick, supra note 3 at $45-46$.

126 Gilmartin, supra note 96 at 34.

127 Grossman, On Combat, supra note 89 at 186.

128 Skolnick, supra note 3 at 47.

129 Although police officers can be injured or killed in car crashes, fires, or any number of types of incidents, I will restrict my comments to those incidents that are purposeful and deliberately caused by an aggressor.

Grossman, On Combat, supra note 89 at 4-6. 
and experienced officers alike. ${ }^{131}$ This sense of purpose is essentially the officers subscribing to a common morality.

Steve Herbert explained that "[l]egality and morality are intimately connected.... [Therefore,] the enforcement of law is often understood by police officers as a moral as well as a legalistic enterprise." ${ }^{132} \mathrm{~A}$ moral construct of policing provides an identity as "warriors in the age-old battle between right and wrong" 133 which gives police officers "a profound sense of the distinctive superiority of their approach to criminal process in comparison to all other approaches." 134 This superiority "works not only to denigrate the bad, but also to glorify the police as valiant defenders of the good." ${ }^{\prime 35}$ Such a construct readily allows one to accept the danger in policing.

Morality in policing, however, has been criticized. To be sure, "the benevolent aspects of policing are often genuine, real, and commendable" ${ }^{36}$ and "[p]olice morality often yields laudable efforts." ${ }^{\prime 37}$ After all, who could disagree with the RCMP's organizational core values of honesty, integrity, professionalism, compassion, accountability, and respect? ${ }^{138}$ That said, Herbert has argued that the police "use a structured morality to avoid the difficult task of discriminatingly interpreting social action." ${ }^{139}$ I disagree. The police role is complex, encompassing a wide variety of tasks that often conflict with each other. ${ }^{140}$ How else can the police navigate the "ambiguous nature of human reality,"141 where there is often no "right" answer, without using a defined, overarching moral compass?

On the other hand, the ability of police morality to "mitigate the inescapable dilemmas of the job”142 generates a strong belief system. Given its potency, this can facilitate a view that the ends justify the means. ${ }^{143}$ As explained by Herbert, "[p]olice actions that are, in fact, inconsistent with the moral cast that molds their self-interpretation can be reinterpreted as excusable given the larger fight for virtue that defines their mission." ${ }^{\text {"144 }}$ This is particularly poignant when considered in light of the use of physical force by the police and the potential for resulting excessive force. Herbert's concern is that excessive force is "more easily condoned if understood as ultimately motivated by a desire to expunge evil from otherwise peaceable streets." ${ }^{145}$

Peter K Manning, Police Work: The Social Organization of Policing (Cambridge: MIT Press, 1977) at 20, n 1.

Herbert, "Morality," supra note 114 at 799.

Steve Herbert, "Police Subculture Reconsidered" (1998) 36:2 Criminology 343 at 360 [Herbert, "Subculture"].

John Charles Curtin, "The Presumption of Innocence: Normative and Constitutional Considerations" (1995) 6:1 John F Kennedy UL Rev 139 at 143.

Herbert, "Subculture," supra note 133 at 360.

Herbert, “Morality,” supra note 114 at 814.

Ibid at 811.

Royal Canadian Mounted Police, "Mission, Vision, and Values," online: <rcmp-grc.gc.ca/aboutausujet/mission-eng.htm>.

Herbert, "Morality," supra note 114 at 813.

Walker, supra note 58 at 58.

Herbert, "Morality," supra note 114 at 813.

Ibid at 812 .

Ibid.

Ibid at 813.

Ibid at 815 . 


\section{THE USE OF FORCE}

The police are justified in using physical force provided it is in the lawful execution of their duties and only as much force as is reasonably necessary is used. ${ }^{146}$ Regardless of its legitimacy, the use of force is a demonstration of interpersonal aggression, which social psychologist Erich Fromm divided into two distinct types: benign and malignant. Fromm distinguished these types of aggression as follows:

This defensive, "benign" aggression is in the service of the survival of the individual and the species, is biologically adaptive, and ceases when the threat has ceased to exist. The other type, "malignant” aggression, i.e., destructiveness and cruelty, is specific to the human species and virtually absent in most mammals; it is not phylogenetically programmed and not biologically adaptive; it has no purpose, and its satisfaction is lustful. Most previous discussion of the subject has been vitiated by the failure to distinguish between these two kinds of aggression, each of which has different sources and different qualities. ${ }^{147}$

The legitimate use of force by police officers is understood to be in society's interests and the reasonableness limitation serves to ensure that the use of force ceases when the threat ceases. ${ }^{148}$ Thus, the lawful use of force by the police fits within the category of benign aggression. However, training officers to use force against another human being, even in entirely legitimate circumstances, is not as simple as it may seem, particularly in the case of lethal force. That is, even so-called "benign aggression" is not necessarily intuitive for police officers.

Grossman noted that throughout military history only a small proportion of soldiers would actually fire their weapons at the enemy, demonstrating that "there is within most men an intense resistance to killing their fellow man. A resistance so strong that, in many circumstances, soldiers on the battlefield will die before they can overcome it." ${ }^{149}$ Grossman specifically points out that in World War II only 15 to 20 percent of American riflemen would fire at the enemy. ${ }^{150}$ Recall that two-thirds of Canadian police officers murdered in the line of duty either did not draw or fire their weapon. Surely some of that was due to lack of opportunity, but how many officers could have fired but simply did not do so, even though their lives were in danger? The police, it seems, are not immune to the resistance to use lethal force. In fact, their situation may be exacerbated by the fear of exposure to supervisor scrutiny, litigation, and public complaints. This reluctance may extend to the use of nonlethal force, as I have personally witnessed police officers freeze when facing a violent criminal, even to the detriment of their partner (me!).

In order to overcome these natural inhibitions, it is not enough to tell police officers when they should use force; they must be conditioned to do so. ${ }^{151}$ For police officers, this

146 Criminal Code, supra note 20, s 25.

147 Erich Fromm, The Anatomy of Human Destructiveness (New York: Holt, Rinehart and Winston, 1973) at 4 [emphasis in original].

Criminal Code, supra note 20, s 25.

Grossman, On Killing, supra note 108 at 4.

Ibid at 16.

Ibid at xxii. 
conditioning is accomplished through shooting at targets shaped as human silhouettes, ${ }^{152}$ performing baton drills using a foam baton, spraying actors with inert oleoresin capsicum spray (pepper spray), and conducting hand-to-hand combat drills. This training enables police officers to overcome natural inhibitions against using force and allows the force to be applied with greater skill, thus improving its effectiveness. However, this training is not the only enabler in the use of force equation.

In war, overcoming the resistance to kill is dependent on creating emotional distance between the soldier and adversary based on cultural, moral, and social grounds, which enables a removal of empathy towards the enemy. ${ }^{153}$ We see that these factors are also at play in the policing subculture. The presumption of guilt defines an adversary, a combative view of policing provides social isolation from that person, and a moral construct of policing establishes moral superiority and affirms the legitimacy of the police officer's actions. This grants the police sufficient emotional distance to be able to use coercive power without guilt.

Utilizing emotional distance to enable a legitimate use of force, though it may seem somewhat troubling, is not necessarily inappropriate and does not automatically translate into excessive force. Indeed, emotional distance can be particularly useful to the police officer if it is used to ward off one's temper in the face of purposeful antagonism, enabling "[a] degree of detachment [which] allows the officer to handle the situation in an impersonal manner." ${ }^{154}$ Emotional distance may also be helpful if, in concert with a combative and moral construct of policing, it produces self-assertive aggression. Fromm defined self-assertive aggression as the ability to "pursue [one's] aim with determination and without being deterred by obstacles.”" ${ }^{55}$ Fromm noted a significant relationship between self-assertive aggression and hostility, which he explained as follows:

The person with an unimpeded self-assertive aggression tends, in general, to be less hostile in a defensive sense than the person whose self-assertion is defective. This holds true both for defensive aggression and for malignant aggression like sadism. The reasons for this are easy to see. As to the first, defensive aggression is a response to a threat. The person with unimpeded self-assertive aggression feels less easily threatened and, hence, is less readily in a position of having to react with aggression. The sadistic person is sadistic because he is suffering from an impotence of the heart, from the incapacity to move the other, to make him respond, to make oneself a loved person. He compensates for that impotence with the passion to

Ibid at 254-61. Setting aside the psychological conditioning aspect of using human silhouette targets for a moment, I will address the practical necessity of doing so. Although it sounds like police are being taught to "shoot to kill," the goal is actually to shoot to incapacitate the threat. It is extremely difficult to deliver precise handgun shots in a dynamic situation. Expecting to be able to shoot the weapon out of an attacker's hand is sheer fiction. Therefore, it is necessary to incapacitate the attacker. Barring a shot to the brain or central nervous system (which would be impossible to reliably do under stress in a dynamic situation), it is the massive hemorrhage of critical organs that offer the best chance for incapacitation. Even then, "the concept of reliable and reproducible immediate incapacitation of the human target by gunshot wounds to the torso is a myth." Simply put, it's not an easy matter to incapacitate someone using a handgun, but shooting at the torso offers the best chance of doing so. In addition, the torso is the largest part of the human body; thus the easiest to hit. For an excellent description of the realities of shooting to incapacitate, see Urey W Patrick, "Handgun Wounding Factors and Effectiveness" (Quantico: US Department of Justice, 1989), online: <www.firearmstactical. com/pdf/fbi-hwfe.pdf $>$.

153 Grossman, On Killing, ibid at 160.

154 Walker, supra note 58 at 271 [citations omitted]. 
have power over others. Since self-assertive aggression enhances the person's capacity for achieving his aims, its possession greatly diminishes the need for sadistic control. ${ }^{156}$

Emotional distance may also be a useful mechanism for the officer to insulate himself from the inevitable constant exposure to human trauma and suffering experienced in a policing career. Much like a physician takes a clinical view of disease and death, does the police officer utilize emotional distance to differentiate himself from the victims and criminals he deals with daily in order to afford himself a sterile perspective from which to conduct his law enforcement role? Walker described the cynicism often found in policing as a positive necessity that protects the officer from the many unpleasant situations he is sure to encounter. ${ }^{157}$ This is persuasive. Also, the emotional distance the officer generates between himself and the population he polices facilitates this necessary cynicism.

That said, danger lurks when emotional distance reaches the point of emotional withdrawal. As Fromm concluded, "[t]here is good clinical evidence for the assumption that destructive aggression occurs, at least to a large degree, in conjunction with a momentary or chronic emotional withdrawal." ${ }^{\prime 158}$ Wartime propaganda aimed at denying an enemy's humanity - a necessary component of emotional withdrawal - has long been a tool of governments to enable their soldiers to kill. ${ }^{159}$ This was frequently accomplished through accentuating cultural and social distance. ${ }^{160} \mathrm{~A}$ similarity is seen in the policing context, where the Christopher Commission found a nexus between the excessive use of force and racial biases. ${ }^{161}$

A demonstration of the tension between necessary emotional distance and negative emotional withdrawal can be found on the t-shirts of a NYPD warrant squad which bore this quote from Ernest Hemingway: "There is no hunting like the hunting of man, and those who have hunted armed men long enough and liked it, never care for anything else thereafter." ${ }^{\prime 62}$ On the one hand, the t-shirt appears to dehumanize the subjects of police investigations by likening them to beasts that best be hunted down and killed, which is surely inappropriate for a policing organization.

On the other hand, this quote may be quite apropos. If we take the definition of hunting to be "the activity of searching for something"163 and the police officers wearing the shirts are, in fact, trying to locate armed criminals, then the quote is a very accurate description of the dangerous work these officers do every day. Adopting a motivational quote that injects emotional distance and accentuates bravery likely builds the self-assertive aggression that is necessary for such a dangerous task, and does not necessarily translate into police abuses.

Ibid at 194 [emphasis in original].

Walker, supra note 58 at 271.

Fromm, supra note 147 at 123.

Grossman, On Killing, supra note 108 at 161.

Ibid at 160 .

"Report of the Independent Commission on the Los Angeles Police Department" (1991) at 69.

Radley Balko, "What Cop T-Shirts Tell Us About Police Culture," Huffington Post (21 June 2013), online: <www.huffingtonpost.com/2013/06/21/what-cop-tshirts-tell-us-_n_3479017.html>.

Merriam Webster Dictionary, sub verbo "hunting," online: <www.merriam-webster.com/dictionary/ hunting>. 


\section{Possibility-Based Thinking}

Police officers face highly ambiguous events, often in rapidly evolving circumstances, rarely while possessing complete information, against a backdrop of potential violence. In order to navigate this difficult landscape, the police are required to maintain an open mind about all possible outcomes to any given scenario. This open-mindedness blends with the presumption of guilt and a competitive policing model to produce possibility-based thinking. Possibility-based thinking is one of the strongest drivers of police behaviour.

Before proceeding, it is necessary to distinguish between possibility-based thinking and probability-based thinking. Possibility-based thinking is a mindset: a habitual or characteristic mental attitude that informs how situations are interpreted and responded to. ${ }^{164}$ Probability-based thinking, on the other hand, is a specific level of belief that can be placed upon the spectrum of certainty ranging (for police purposes) from mere suspicion to reasonable grounds to believe. Although mere suspicion, being at the lowest end of the spectrum of belief, will often be based solely upon possibility-based thinking, the terms are not interchangeable. That is, for the argument below, possibility-based thinking is a much broader term than just suspicion as the former describes a general attitude, and the latter describes a specific level of belief that informs a particular decision in a discrete scenario.

The interconnectedness of possibility-based thinking, the presumption of guilt, and a competitive model of policing can be described as follows. The presumption of guilt, when motivated by the metrics of policing and the requirements of certain legal authorities, is typically confined to discrete investigations and individual suspects. However, when combined with a competitive policing model, the net is cast much wider. That is, through a competitive policing lens, the police see the public at large as either adversaries or possible adversaries. This view is supported by the practice of hyper-vigilance. Thus, from a possibility-based mindset, the presumption of guilt can be applied not only against criminals identified by objectively discernible facts, who can be described as actual or probable criminals, but also against possible criminals (everyone else).

It could be argued that possibility-based thinking is caused by the crime-fighting image that dominates the policing subculture. That is, if a police officer sees fighting crime as "real police work," then every interaction with the public will be conducted with a view towards making it fit within that framework. The starting point of every encounter will be an assessment of whether or not it is of a criminal nature, and probably with a preference that it is. Possibility-based thinking greatly assists such assessments. Greg Marquis explained the relationship between possibility-based thinking, police subculture, and the presumption of guilt:

By mid-century police on the beat ... were expected to know local criminals, chiefly thieves, burglars, fraud artists, prostitutes and fences, by name and reputation. They were also instructed to ascertain likely criminals

- strangers - by their appearance, acquaintances, and circumstances. The career cop learned that crime was an attitude and lifestyle, not simply an action or series of actions. This occupational skill, a rejection of the 
legal doctrine ‘innocent until proven guilty,' had, as a number of historians point out, a profound legacy for the twentieth century. ${ }^{165}$

Approaching the matter from a different direction, Skolnick discussed the persistent suspiciousness of policing, ${ }^{166}$ particularly focused on potential violence, as leading to officers developing a "perceptual shorthand to identify certain kinds of people as symbolic assailants." 167 This perceptual shorthand is a manifestation of possibility-based thinking and, as with Marquis' construct, is a result of the policing subculture.

While these arguments are certainly not without merit - since one would expect the police to be motivated to detect even well-concealed crime and to stay safe while doing so - they do not present the complete picture. The policing subculture is not the sole, or even the primary, contributor to possibility-based thinking. Instead, the primary contributors are investigative necessity and officer safety. These motivations serve legitimate, beneficial purposes. That said, officers face challenges when they discover that possibility-based thinking is distinctly different than the probability-based thinking that the courts expect the police to utilize when deciding whether the use of a particular authority is appropriate. The difference between mindset and belief and the difficulty for the officer to transition from one to the other, especially in the heat of the moment during a rapidly evolving investigation, results in inevitable tension between the courts and the police.

\section{A. INVESTIGATIVE NECESSITY}

When conducting an investigation, a police officer is at best faced with incomplete information and at worst people purposely providing inaccurate information. Even with accurate information, human behaviour is such that the ultimate outcome of a scenario cannot be reliably predicted. Any police officer can easily recount incidents where, at the conclusion of the investigation, the result was completely unexpected and defied normal explanation. Recall that Canada's most prolific serial killer, Robert Pickton, was caught because a junior officer obtained a simple search warrant for firearms on Pickton's farm. ${ }^{168}$ Of course, the converse is also true, and extremely suspicious circumstances frequently turn out to be completely benign.

It is easy to see how open-mindedness is a virtue when it comes to conducting sound investigations. Examples abound in which adherence to this rule paid dividends and violations resulted in disaster. Compare, for example, two different traffic stops conducted by RCMP officers. In the first, a junior police officer in northern British Columbia pulled over a vehicle leaving a logging road in the winter. Although dealing with a simple speeding infraction, the officer was alive to the possibility that the driver could have been poaching on the logging road, and had a conservation officer retrace the tire tracks in the snow. As it turned out, the recently dumped body of a young girl was found. The driver, Cody 
Legebokoff, was charged with that murder and the murders of three other women. ${ }^{169} \mathrm{~A}$ burgeoning serial killer was caught, all because an officer approached a seemingly routine event with an open mind.

Contrast that to the traffic stop conducted by a veteran RCMP officer who pulled over a speeding van on a highway outside of Calgary. The officer gave a speeding ticket to the driver, thinking nothing of the ten-year-old girl who sat quietly in the vehicle. The officer treated the situation as routine, which by all accounts is how the situation presented itself. However, had the officer applied a more suspicious mindset he may have sought out the driver's criminal history, finding previous convictions for sexual assaults and kidnapping. Surely such a discovery would have prompted some inquiries about the girl, who, it turns out, had moments before been abducted from a Calgary mall. Instead of rescuing the girl, he let the driver go with victim still in tow. ${ }^{170}$

Failing to apply possibility-based thinking — that is, accepting situations at face value can be the result of either naivety or laziness. Doing so in serious investigations can seriously impede, if not completely undermine, subsequent efforts at solving crime. Such was the case in the disappearance of Christine Jessop, a nine-year-old girl who went missing from her home in Newmarket, Ontario. There is nothing immediately suspicious about a missing child — it is a common occurrence that is almost always resolved without incident. However, Jessop would later be found murdered, and her neighbour, Guy Paul Morin, was wrongfully convicted of the crime. The Inquiry looking into the wrongful conviction stated the following about the investigative necessity of possibility-based thinking:

In my view, the problem here was not that the police characterized their initial involvement as a missing person investigation. The problem was that the officers did not conduct themselves mindful of the possibility that they were dealing with a serious crime. As a result, opportunities were missed that ultimately affected the quality and effectiveness of the criminal investigation. Some officers appeared to have a prevailing hope, long after the exhaustive search, that Christine would be found alive. This hope or optimism may have precluded a more detailed and focused investigation. ${ }^{171}$

On the converse, the lack of possibility-based thinking, particularly when combined with an excessively strong presumption of guilt, can result in "the single-minded and overly narrow focus on a particular investigative or prosecutorial theory, so as to unreasonably colour the evaluation of information received and one's conduct in response to that information." 172 This type of closed-mindedness has been referred to as tunnel vision, and the resulting confirmational bias it generates has been blamed for numerous wrongful convictions. ${ }^{173}$ As explained by Peter deC. Cory:

Tasmin McMahon, "Cody Alan Legebokoff: The country boy accused in the murders of four B.C. women,” National Post (18 October 2011), online: < news.nationalpost.com/news/cody-alan-legebokoffsuspected-serial-killer>.

$R v$ Dionne, 2012 ABPC 261, [2012] AJ No 959 (QL); Josh Wingrove, “Calgary girl safe after police scare suspected abductor at traffic stop," The Globe and Mail (25 February 2011) online: <www.the globeandmail.com/news/national/calgary-girl-safe-after-police-scare-suspected-abductor-at-trafficstop/article597354>. Morin Report, supra note 63 at 652 [emphasis in original].

Ibid at 1134 .

Sophonow Inquiry, supra note 9; Marshall Commission, supra note 77 at 3; Morin Report, supra note 63. 
Tunnel Vision is insidious. It can affect an officer or, indeed, anyone involved in the administration of justice with sometimes tragic results. It results in the officer becoming so focussed upon an individual or incident that no other person or incident registers in the officer's thoughts. Thus, tunnel vision can result in the elimination of other suspects who should be investigated. Equally, events which could lead to other suspects are eliminated from the officer's thinking. Anyone, police officer, counsel or judge can become infected by this virus. $^{174}$

We therefore see that possibility-based thinking is an investigative requirement that cuts both ways. On the one hand, it allows a suspicious mindset to exist even in the absence of outwardly suspicious circumstances, which enables the discovery of crime that would otherwise go undetected. On the other hand, possibility-based thinking is necessary to ward off an excessively suspicious mindset that results in tunnel vision.

That said, the investigative application of possibility-based thinking presents dangers when the officer fails to transition to probability-based thinking. This tendency has been amply demonstrated by numerous police officers who were candidates on a basic search warrant writing course that the author teaches on. The course presents a very simple scenario: two snowmobiles, a blue one and a yellow one, are stolen. A few weeks later, a tip is received that a suspect has the yellow snowmobile. Surveillance confirms the yellow snowmobile is parked on the suspect's property. The students are asked to draft a search warrant but are not given direction on what items they are to search for.

Most junior officers tend to list both snowmobiles on the warrant, even though there is nothing to say the suspect has the blue snowmobile. When asked why they did so, the students will typically give one of two answers: “because we don’t let criminals keep stolen property" (competitive-based thinking), or "if the yellow one is there the blue one might be too" (possibility-based thinking). It is when the police take such investigative actions without making the transition from mindset to belief that problems result in court, as described by Christopher Slobogin:

[A]t the time they engage in a search or a seizure police usually believe, in good faith, that they have the goods on the suspect. But when they truthfully explain themselves to a judge, they often find that their suspicion, based on experience and gut feeling, was an unconstitutional "hunch.”175

\section{B. OFFICER SAFETY}

Hypervigilance - a "perceptual set of elevated alertness of the surroundings"176 — is merely possibility-based thinking specific to officer safety concerns. It is easy to see how an officer is motivated to engage in hyper-vigilance. If the officer concludes that there is no threat when there is one, harm can result. On the other hand, if the officer perceives a threat where there is none, the officer loses nothing (from a safety perspective). Officer safety concerns are a strong motivator of police behaviour, and within the policing profession a 
"normative order of safety is invoked with impressive frequency." 177 This behaviour is purposeful, as viewing the world through a threat-based perspective requires the conscious adoption of a mindset that sees unfolding events as potential hazards. Of course, it is difficult to fault a police officer who errs on the side of caution when approaching situations of unknown risk. The courts have recognized that caution may, in hindsight, be proven to have been unnecessary, but that does not invalidate its practice:

It is often said of security measures that, if something happens, the measures were inadequate but that if nothing happens, they were excessive. These sorts of after-the-fact assessments are unfair and inappropriate when applied to situations like this where the officers must exercise discretion and judgment in difficult and fluid circumstances. The role of the reviewing court in assessing the manner in which a search has been conducted is to appropriately balance the rights of suspects with the requirements of safe and effective law enforcement, not to become a Monday morning quarterback. ${ }^{178}$

Although " $[\mathrm{w}]$ hen it comes to officer safety ... police officers should be given a good deal of leeway and second guessing should be avoided," ${ }^{179}$ the police do not have carte blanche to conduct themselves however they wish in the name of officer safety, especially in regards to the use of force. As put by Justice Fruman:

\begin{abstract}
Essentially, s. 25(1) is a safe harbour from liability for those who are required to enforce the law. The police are often placed in situations in which they must make difficult decisions quickly, and are to be afforded some latitude for the choices they make. Courts recognize that law enforcement is dangerous; no one wants police officers to compromise their safety. On the other hand, s. 25(1) is not an absolute waiver of liability, permitting officers to act in any manner they see fit. The police are entitled to be wrong, but they must act reasonably. ${ }^{180}$
\end{abstract}

While the officer's threat-based mindset is a useful tool to inform the officer of what factors ought to be considered when forming beliefs that justify action, it does not provide belief in and of itself. That is to say, a police officer's thought process may be motivated by possibility-based thinking, but the officer's actions can only be motivated by probabilitybased thinking, and even then only when the belief meets the requisite threshold. In meeting this required threshold of probability, an officer's subjective beliefs must be based on objectively discernible facts. ${ }^{181}$

Failure to appreciate the distinction between mindset and belief can result in the officer's actions being found to be unconstitutional or worse, unlawful. While the former risks the inadmissibility of evidence, ${ }^{182}$ the latter risks the officer forfeiting his protections under the Criminal Code ${ }^{183}$ This reality has been lost on some officers, who cling to the police adage that "it is better to be judged by twelve than carried by six." But as the gavel strikes, the officer who finds himself a convicted criminal is unlikely to find solace in such bravado.

Herbert, "Subculture," supra note 133 at 357.

$R v$ Cornell, 2010 SCC 31, [2010] 2 SCR 142 at para 24.

$R v$ White, 2007 ONCA 318, 85 OR (3d) 407 at para 54.

Crampton $v$ Walton, 2005 ABCA 81, 40 Alta LR (4th) 28 at para 22 [citations omitted, emphasis added]. Nasogaluak, supra note 35 at para 34.

Charter, supra note 18, s 24(2).

See e.g. Criminal Code, supra note 20, ss 25-26; Cluett v The Queen, [1985] 2 SCR 216; $R v$ Munson, 2003 SKCA 28, [2004] 2 WWR 107. 
Such was the situation that RCMP Constable David Pompeo found himself in. ${ }^{184}$ Pompeo and his partner pulled over a car because they knew the driver (Gillespie) to be prohibited from driving. They also knew that Gillespie had a criminal record for a robbery involving a firearm from several years prior. When they tried to pull the car over, Gillespie instead turned onto a dead end, poorly lit roadway, ultimately stopping in the driveway of his passenger's residence. Gillespie got out of the vehicle and made furtive movements with his hands, reaching for his pocket. Pompeo drew his firearm. Gillespie continued to reach in his pocket and advanced towards Pompeo. Gillespie withdrew his hand from his pocket, began to lie down in response to Pompeo's commands, and then put his hand back into his pocket. At this point, Pompeo was convinced that Gillespie was reaching for a gun and, if allowed to retrieve it, would be able to shoot Pompeo. Pompeo fired one round at Gillespie, injuring him. As it turns out, Gillespie was not in the possession of a gun. Pompeo was convicted of aggravated assault.

Notwithstanding that Pompeo's conviction was overturned on appeal, the scenario is instructive on many levels. Firstly, it demonstrates the tension between the benefits of possibility-based thinking in the investigative sense, and the impact such a mindset has on officer safety practices. A police officer never knows what sort of criminal activity he may have stumbled upon and must keep an open mind to all potentialities. In the investigative sense, it was desirable for Pompeo to be alive to the possibility that he was dealing with something far more serious than a simple prohibited driver. It was possible that Gillespie had just committed a murder or was in possession of a large quantity of drugs. However, mere possibilities cannot justify the use of force. Justice Wood's conclusion illustrates this tension:

While all of the information at Const. Pompeo's disposal indicated that considerable caution needed to be exercised when dealing with Mr. Gillespie, none of the actual circumstances leading up to their chance encounter that evening could reasonably have supported the conclusion, just 19 seconds after the siren was first sounded, that he was intent on shooting the officer in order to escape the consequences of a conviction for driving while prohibited. ${ }^{185}$

This difficulty demonstrates that with respect to officer safety, the tension between possibility-based thinking and probability-based thinking can only be relieved at the officer's legal or physical peril. A police officer may believe that someone has a concealed gun in their pocket, but cannot lawfully take action unless that belief is based on a credibly based probability, thus reaching the reasonable grounds to believe standard. ${ }^{186}$ If the officer's observations up to that point are not sufficient for that purpose, then the most likely factor that would change the calculation would be the suspect actually pulling out a firearm. By that time, it would be too late, because the suspect would be able to shoot the officer before the officer could react — even if the officer is holding the suspect at gunpoint. ${ }^{187}$ The officer is in the testimony of the various witnesses, I will rely on the testimony of Constable Pompeo as outlined in the since-overturned trial judge's decision as the narrative of the incident. This case was overturned on appeal: $R$ v Pompeo, 2014 BCCA 317, 313 CCC (3d) 539. 
faced with a choice to shoot the suspect and face legal risk, or not shoot and face physical risk. Perhaps that unenviable position is just the risk inherent in policing.

Pompeo also demonstrates the potential hazard of tunnel vision (being the absence of possibility-based thinking) when applied to officer safety considerations. That is, if a threatbased mindset results in a conclusion of a particular risk, the officer must be mindful of the dangers of conformational bias that will lead the officer to an erroneous conclusion as to the actual probability of said risk. As applied in Pompeo:

\footnotetext{
Const. Pompeo testified that he was constantly reassessing the situation and reacting to what was happening in front of him. However, again on his own evidence, he was convinced Mr. Gillespie had a firearm from the moment the latter got out of the Saturn and any "reassessing" that took place from that point on only served to identify more threat cues that confirmed that belief and escalated his fear, anxiety and conviction that he was at risk of being killed. The obsession that he was facing a lethal threat, combined with his rapidly escalating fear and anxiety interfered with his ability to recognize alternatives to those threat cues. ${ }^{188}$
}

Finally, Pompeo demonstrates just how difficult it is to articulate bona fide probabilitybased conclusions that are based on nuanced physical observations and applications of policing experience. In the absence of being able to articulate such observations, the officer will appear to be motived entirely by possibility-based thinking. For example, in Pompeo, the officers came to the conclusion that Gillespie was going to flee based on a rapid left turn that he made when the police turned on their lights. This conclusion formed part of the basis of Pompeo's risk assessment. Yet at trial, it was difficult for Pompeo to articulate why he thought Gillespie was fleeing; the conclusion simply did not withstand scrutiny after an analysis of the times of radio transmissions and distances travelled showed the vehicle drove only a short distance, and only at an average of 20 kilometres per hour. ${ }^{189}$

While it is possible that Pompeo and his partner were mistaken in their conclusion, it is also possible that they had accurately discerned an unusual driving behaviour based on very limited information. This is not a phenomenon limited to policing. Certainly any driver has had the experience of predicting when another motorist is about to cut them off and is thereby able to avoid a collision. However, the driver would likely be at a loss for an explanation as to why they came to that conclusion. They may be able to grasp at minor factors such as speed and movements in the lane, but under capable cross-examination these factors would be seen to be barely removed from normal driving patterns. Such observations just do not translate sufficiently well into testimony to qualify as objectively discernible facts. Certainly the driver would have difficulty establishing reasonable grounds that they were about to be cut off. Yet few would doubt the human capacity to accurately discern such things.

Readers of Malcolm Gladwell's popular book Blink ${ }^{190}$ will be familiar with similar tales of art experts, psychologists, and businessmen who have shown a knack for making

Malcolm Gladwell, Blink: The Power of Thinking Without Thinking (New York: Back Bay Books, 2005). 
incredibly accurate conclusions on the "narrowest slivers of experience.”191 However, even if one accepts that police officers are capable of accurate "[s]nap judgements and rapid cognition"192 based on their experience and training, that does not supplant the rigorous and independent scrutiny of the courts. ${ }^{193}$ Such snap judgements, even if accurate, defy explanation and an officer would be wise to avoid, if at all possible, taking action based on them.

That is not to say that police actions should never be based on rapid cognition. I recall being a rookie officer making an arrest when my "ability to extract an enormous amount of meaningful information from the very thinnest slice of experience"194 had a tremendous impact on a critical incident. In my case, we had received information that three suspects who were out on bail for a violent robbery were breaching their no contact orders and had armed themselves in preparation for another heist. Two of the suspects were arrested at their house, and both were found to be armed with knives and bear spray hidden in their jackets. I found the third suspect walking towards the others' house a few minutes later.

Initially the suspect was cooperative and put his hands behind his back when I told him he was under arrest. When I tried to put on the handcuffs, however, things changed. He brought his hands in front of him and began digging for something in his bulky winter jacket, positioning his body so that I could not see what he was doing. Given his violent criminal record, his history of using weapons, the information we had received about his intended crime, his cohorts being armed, and the manner in which he was digging in his jacket there was but one conclusion: he was getting a weapon. I pushed him from behind, knocking him off balance. I used that time to back a few steps away and draw my pistol. When he turned around he was holding a large machete, which he began to raise.

At that point I had to make the crucial decision, to shoot or not to shoot. I knew that he could swing the machete and cleave my head wide open before I could pull the trigger in response; if I were going to shoot I would have to do it before he began his swing. If I could not wait for him to swing the machete, then by what calculation should I make the decision whether to shoot? All of the objectively discernible factors indicated that my life was in immediate danger, for why else would he brandish a machete except to use it on the police officer who stood before him? Yet I did not shoot and not out of reluctance to use force, for there was no question in my mind about his malevolent intentions when he drew the machete.

As the suspect turned towards me I watched as his expression turned from aggression to surprise to surrender, no doubt motivated by the experience of suddenly staring down the barrel of my gun. I watched his body language, and saw the moment his shoulders relaxed and he stopped raising the machete. All of that happened in a fraction of a second, seemingly insufficient time to make such observations. Instead of shooting, I told him to drop the machete, and he did. In a fraction of a second, I had been able to interpret subtle nuances of behaviour such that the entire interaction changed. However, to articulate what I saw and why those observations informed my decision not to shoot is impossible; I would never be 
able to support my subjective belief of his capitulation with objectively discernible facts. How does one testify convincingly about facial expressions and body language? Of course, since there was no use of force, such a justification was not necessary.

However, one can easily imagine a scenario where the opposite is true and similarly nuanced observations give rise to a legitimate fear for one's safety. Unfortunately, subtleties do not translate well into testimony, and the courts have great difficulty in confirming that actions based on such were, in fact, reasonable. Even efforts to buttress the significance of nuanced observation by drawing on officer experience and training often fall flat as it is difficult to discern experience from intuition in such scenarios. ${ }^{195}$

A corollary to these considerations is that even the exercise of officer safety practices that do not involve the use of force may still have an impact on the legalities of an interaction with the public. That is, the exercise of possibility-based thinking in the physical safety sense may have legal implications that require the application of probability-based thinking in order to justify. For example, officers approaching someone on the street may take precautionary measures such as having a numerical advantage, taking positions that offer a tactical advantage, and telling the person to keep their hands out of their pockets. Such actions are motivated by the possibility that the person is a threat, but may create a sufficient atmosphere of coercion that the person will be found to be detained. ${ }^{196}$ Of course, detention requires an application of probability-based thinking reaching the threshold of reasonable suspicion. ${ }^{197}$ By applying possibility-based thinking in officer safety practices but failing to apply probability-based thinking in the investigative sense, police officers can create a situation where the entire interaction is fatally flawed. An acceptable solution to this difficulty is not readily apparent.

Possibility-based thinking is an absolutely essential skill, both in the investigative sense and in regards to officer safety. A policing mindset that is open to all possibilities has a legitimate role in investigations. However, that mindset must eventually give way to case specific beliefs based on objectively discernible facts that fit within a matrix of acceptable standards of reasonableness. As explained by Chief Justice McLachlin:

Police, like other professionals, exercise professional discretion.... Discretion, hunch and intuition have their proper place in police investigation. However, to characterize police work as completely unpredictable and unbound by standards of reasonableness is to deny its professional nature. Police exercise their discretion and professional judgment in accordance with professional standards and practices, consistent with the high standards of professionalism that society rightfully demands of police in performing their important and dangerous work. ${ }^{198}$

See e.g. $R$ v Payette, 2010 BCCA 392, 259 CCC (3d) 178 (officer experience failed to even meet the threshold of reasonable suspicion, where Justice Neilson found: "While I appreciate the objective reasonableness requirement must be viewed in the light of the investigating officer's background and experience, deference to an officer's intuition must not render the objective element of the inquiry meaningless” at para 25). See also Chehil, supra note 29 at para 47. $R v$ Grant, 2009 SCC 32, [2009] 2 SCR 353 at paras 48-52 [Grant]. Mann, supra note 15.

Hill v Hamilton-Wentworth Regional Police Services Board, 2007 SCC 41, [2007] 3 SCR 129 at para 52. 
Notwithstanding its necessity, possibility-based thinking poses risks when carried too far. This is especially acute in officer safety practices since risks to personal safety motivate a significantly different response than other stimuli. ${ }^{199}$ In responding to potential threats, possibility-based thinking can merge with the presumption of guilt and a crime fighter construct of policing to produce aggressive policing styles. Indeed, officer safety practices that result from possibility-based thinking can produce detrimental effects when officers become "overly fearful and thus overly suspicious of any who posed even a remote threat."200

For the officer, to ignore possibility-based thinking as meaningless hunches is to reject sound officer safety and investigative practices. For the courts, accepting possibility-based thinking as the equivalent to probability-based thinking is to allow indiscriminate police action and is simply not possible. ${ }^{201}$ For both, placing trust in the actual low prevalence of attacks against police — or the unlikelihood that a seemingly routine investigation is anything but - is to ignore the problem. Investigative requirements, officer safety concerns, and the need for rigorous judicial scrutiny are not easily reconciled.

Of course, this difficulty manifests itself at trial - usually that of the suspect but sometimes that of the officer - where the officer provides evidence on their actions. Justice O’Donnell drew an interesting characterization of police officer evidence as fitting somewhere on a spectrum between rationalization and justification. ${ }^{202}$ The distinction between rationalization and justification highlights the differences in police evidence resulting from applications of possibility-based thinking versus probability-based thinking. That is, when police action is based solely on a possibility-based mindset, the only way to support said action is through after-the-fact rationalization. On the other hand, probabilitybased thinking results in beliefs based on objectively discernible facts, which leads to justifiable actions. Possibility-based thinking, on its own, is simply incapable of withstanding judicial scrutiny. That said, the purpose of possibility-based thinking is not to form grounds of belief, so its limitations do not invalidate its practice.

\section{RESUlting TENSIONS}

Canadian laws pertaining to police authority are permissive but lack clarity and comprehensiveness. Understandably, the police sometimes have difficulty navigating the “complex labyrinth”203 of Criminal Code provisions which have been described as suffering from "bewildering complexity"204 and lacking "precise definition."205 The "scattered collection of statutory and common law rules that make up the law of police powers in Canada” ${ }^{206}$ presents difficulties to officers on the street. These were explained by Justice Hill:

Grossman, On Combat, supra note 89 at 4; Skolnick, supra note 3 at 45-46.

Herbert, "Subculture," supra note 133 at 358.

Chehil, supra note 29 at para 25.

$R v$ Jackson, 2011 ONCJ 228, 235 CRR (2d) 289 at para 40.

Michal Fairburn, “Twenty-Five Years in Search of a Reasonable Approach” in Cameron \& Stribopoulos, supra note 37 at 55 (discussing search provisions).

Don Stuart, Charter Justice in Canadian Criminal Law, 3rd ed (Scarborough: Carswell, 2001) at 260 (discussing the provisions of the Criminal Code, supra note 20, s 495(2) regarding the limitations of police arrest powers). See also Stribopolous, "Unchecked Power," supra note 72 at 239-40. Hill, supra note 38 at 185.

James Stribopoulos, "Has the Charter Been for Crime Control? Reflecting on 25 Years of Constitutional Criminal Procedure in Canada” in Margaret E Beare, ed, Honouring Social Justice: Honouring Dianne Martin (Toronto: University of Toronto Press, 2008) 351 at 358 [Stribopoulos, “Crime Control”]. 
"In street policing, officers need to make quick decisions and to remain responsive to changing information. In such a dynamic and fluid environment, a police officer needs to know and be able to apply clear rules almost automatically. There is no time to 'grapple...with complexities' in the law.”207

Just how determinant the law is of police behaviour is unclear, but certainly in the absence of lawful authorities that are easily understood and applied, the police will conduct themselves in a pragmatic way that best fits within how they perceive their role in society and the criminal process. ${ }^{208}$ This allows for the role of the police officer to be heavily influenced by their own interpretation of policing through a cognitive lens that is tinted by a strong subscription to the crime control model, a combative and moralistic construct of policing, and a presumption of guilt. This cognitive lens is not necessarily inappropriate; in many ways it is borne out of necessity and has many benefits. However, if the police role is defined solely by these factors, then it risks a misconstrual of the purpose of the police, leading to a misapplication of the processes by which those aims are achieved.

The crime control model holds that the purpose of the police is to be as efficient as possible in solving crime. To achieve that efficiency, the model requires an investigative process with "as few restrictions as possible" ${ }^{209}$ on police authority. This inevitably leads to the conclusion that the duty to enforce the law confers, or ought to confer, an authority to do so. Of course, "[p]olice powers and police duties are not necessarily correlative." 210 Subscribing to the crime control model in this manner leads to the issues described by James Stribopoulos:

In legally grey areas, the police officers we should be most concerned about, those who see their role in purely instrumental terms, are also the ones most likely to see legal ambiguity as a justification for testing the legal boundaries. Put another way, legal uncertainty may actually be taken by some police officers as justification for assuming lawful authority unless and until its absence is made crystal clear. ${ }^{211}$

From a competitive perspective, the purpose of the police is to win the "war on crime." Under such a combatant structure, the rules of the criminal process become the rules of competition, designed to benefit one side or the other. Any rule that limits the powers of the police will be viewed as "undue interference with their task of the efficient dispatch of villains behind bars where such villains belong." 212 This type of perspective impairs the ability of police officers to appreciate the benefits of proper due process and may therefore reduce adherence to rules designed to ensure fundamental fairness.

A re-interpretation of the purpose of policing as being a higher moral cause enables seductive reasoning that a duty to suppress crime imparts moral, and therefore lawful,

Hill, supra note 38 at 209-10 [citations omitted].

Herbert, "Subculture," supra note 133 at 352.

Packer, supra note 1 at 13.

Mann, supra note 15 at para 35.

Stribopoulos, "Crime Control," supra note 206 at 363 [citations omitted].

Roger A Shiner, “Citizens” Rights and Police Powers” in Macleod \& Schneiderman, supra note 73, 59 at 60 . 
authority to do so in every circumstance and by any means necessary. ${ }^{213}$ Justifying actions according to the supremacy of morals rather than in accordance with subservience to the law, violates "[t]he pledge to avert tyrannical public policing [which] was to be secured by the rule of law.",214

Finally, as previously argued, the cognitive lens of the police is heavily influenced by the presumption of guilt. This can readily be contrasted to the presumption of innocence - the proverbial "golden thread" 215 of Canadian criminal law. ${ }^{216}$ The Supreme Court of Canada explained not only the importance of the presumption of innocence, but the resulting perspective that it ought to provide:

The presumption of innocence is a hallowed principle lying at the very heart of criminal law.... The presumption of innocence protects the fundamental liberty and human dignity of any and every person accused by the State of criminal conduct.... It ensures that until the State proves an accused's guilt beyond all reasonable doubt, he or she is innocent. This is essential in a society committed to fairness and social justice. The presumption of innocence confirms our faith in humankind; it reflects our belief that individuals are decent and law-abiding members of the community until proven otherwise. ${ }^{217}$

This default belief that "individuals are decent and law-abiding members of the community until proven otherwise" ${ }^{218}$ starkly contrasts against the "remarkable agreement on the characteristics believed to make up the police mentality ... [which] includes suspicion, conventionality, cynicism, prejudice, and the distrust of the unusual.”219 The police officer, whose conception of order is shaped by persistent suspicion, ${ }^{220}$ is "especially attentive to signs indicating a potential for violence and lawbreaking." 221 This mentality is predicated on a presumption of guilt. The key difference between the courts and the police, however, is not their faith (or lack thereof) in humankind, but rather how they use those basic premises to advance investigations or inform judgments.

For a police officer conducting an investigation, the relevant threshold of belief that must be established to enable investigative action is, for the most part, reasonable grounds to believe. For the courts, the relevant threshold is one of proof beyond a reasonable doubt. Typically, those thresholds of beliefs are placed at different places along a spectrum of certainty. ${ }^{222}$ This seems to lead to a model requiring the courts to be more sure than the

As aptly stated by Chief Justice Dickson in the dissent in Dedman, supra note 8 at 12: “[i]t is ... necessary to distinguish the duties of police officers from the power, or lawful authority, they possess to execute those duties. The fact that a police officer has a general duty to prevent crime and protect life and property does not mean that he or she can use any or all means for achieving these ends.”

Alan Young, "All Along the Watchtower: Arbitrary Detention and the Police Function” (1991) 29:2 Osgoode Hall LJ 329 at 335.

Woolmington v Director of Public Prosecutions, [1935] AC 462 at 481 (HL).

Kent Roach, “The Importance of Air of Reality Tests” (2004) 49:1 Crim LQ 1 at 1.

$R$ v Oakes, [1986] 1 SCR 103 at 119-20.

Ibid at 120 .

Balch, supra note 5 at 106.

Skolnick, supra note 3 at 48.

Ibid at 44 [emphasis added].

Mugesera, supra note 28, en banc ("the 'reasonable grounds to believe' standard requires something more than mere suspicion, but less than the standard applicable in civil matters of proof on the balance of probabilities" at para 114); $R$ v Lifchus, [1997] 3 SCR 320 [Lifchus] ("the standard of [proof beyond a reasonable doubt] is higher than the standard applied in civil actions of proof based upon a balance of probabilities yet less than proof to an absolute certainty” at para 14). 
officer was of the accused's guilt. However, when considered via presumptions of guilt and innocence, an entirely different conception is revealed. From a starting point of these different presumptions, reasonable grounds to believe and proof beyond a reasonable doubt are found to be different in kind, not degree.

The tool of the police officer is reasonable grounds to believe, and it is assessed through a lens of a presumption of guilt. These concepts are as inextricably linked as proof beyond a reasonable doubt and the presumption of innocence, which was described by Justice Cory:

[T] he standard of proof beyond a reasonable doubt is vitally important since it is inextricably linked to that basic premise which is fundamental to all criminal trials: the presumption of innocence. The two concepts are forever as closely linked as Romeo with Juliet or Oberon with Titania and they must be presented together as a unit. If the presumption of innocence is the golden thread of criminal justice then proof beyond a reasonable doubt is the silver and these two threads are forever intertwined in the fabric of criminal law. ${ }^{223}$

When the presumption of guilt animates an assessment as to whether or not the reasonable grounds standard has been met, it is essentially an exercise in confirmation - a question of whether the evidence supports the existing theory of guilt. However, assessing proof beyond a reasonable doubt from a presumption of innocence is an exercise in confutation - a question of whether the evidence refutes the existing theory of innocence. With this important distinction in mind, it becomes clear that the courts and the police do not use congruent calculations where the resulting certainty of guilt needs to be greater for the courts than it does for the police. Instead, the police and the courts use completely different formulas.

Herein lies the source of much of the tension between police operations and the court: evidence is collected from a presumption of guilt, but must be analyzed from a presumption of innocence, resulting in a conceptual chasm that is not easily spanned. A police officer who approached an investigation from a presumption of guilt and acquired reasonable grounds to gather sufficient evidence to allow for charges is faced with the impossible task of watching the courts assess the accused's guilt based on an application of proof beyond a reasonable doubt from a starting point of a presumption of innocence. This requires the officer to replace what she concluded to be true (the accused is guilty) with an assumption of what she knows to be untrue (that the accused is presumptively innocent) and adding the dimension of legal guilt - a measurement of due process - to the equation. This is an impossible leap of perspective.

Notwithstanding the potential drawbacks, this article argues that the policing cognitive lens is borne out of practical necessity. Unfortunately, "[t]he practical concerns of police do not enter the thinking of the judiciary on the problem of how policemen should act in carrying out their duties."224 Thus, understanding the source of the cognitive lens of the police officer is not the real exercise, even though it is instructive to do so. The real goal is understanding the impact that lens has on police actions and subsequent analysis by the court. This impact is determined by the false consensus effect and the fundamental attribution error. 
The false consensus effect is the tendency for a person to believe that others hold the same beliefs and interpret data and situations in the same manner. ${ }^{225}$ Thus, a police officer likely believes that others in the criminal process interpret the law and its application in the same manner as she does. Of course, judges and lawyers likely have their own cognitive lenses coloured by an entirely different set of practical necessities incorporating concepts of due process, the presumption of innocence, proof beyond a reasonable doubt, and a focus on broader systemic concerns beyond the criminal offence at hand. ${ }^{226}$

Adding to this difficulty is that the potential for false consensus is greatly increased by the imprecise nature of the law. That is, since the laws are written in vague, subjective terms (such as reasonable, arbitrary, suspicion, and belief) they are subject to a high degree of interpretation, and the more a term is subject to construal, the higher the likelihood of false consensus. $^{227}$

If we accept that the police and the courts view the law and its application through different cognitive lenses - and that each is prone to mistakenly thinking that there is a consensus confirming their interpretation of legal standards - then any time the actions of the other party fail to fit into that false consensus, the behaviour can be attributed to negative intentions by the other party instead of to situational factors. This, of course, is the fundamental attribution error — a tendency to explain a person's behaviour by overestimating the effect of disposition or personality while underestimating the effect of the situational factors surrounding the person's actions. ${ }^{228}$

For the police officer, this may result in holding the criminal process in bitter contempt. A defence lawyer's argument against police action is not then appreciated as a necessary part of due process, but rather a demonstration of the lawyer's willingness to use due process as a veil for intellectual games of semantics that are played at a cost to society and to the benefit of criminals. A judge's decision in favour of due process can be interpreted as a demonstration of the judge's lack of appreciation for reality, indifference to the suffering of the victim, or outright hostility towards the police. While the legal industry is not beyond reproach, adopting the above mentality presents incredible dangers. If the police believe that justice cannot be found in the courts, then they will dispense it in the alleys.

For the courts, the fundamental attribution error is a constant danger when assessing the actions of the police. An example of such can be found in the case of Nicholas Ebanks, who was heard planning to commit a murder while his communications were being intercepted. ${ }^{229}$ The trial judge ruled that the affiant on the Part VI application had "intentionally omitted ...

See generally Lee Ross, David Greene \& Pamela House, “The 'False Consensus Effect': An Egocentric Bias in Social Perception and Attribution Processes” (1977) 13:3 J Experimental Social Psychology 279. The cognitive lens of lawyers and judges are beyond the scope of this article (and outside the realm of my experience).

Thomas Gilovich, “Differential Construal and the False Consensus Effect” (1990) 59:4 J Personality \& Social Psychology 623.

Edward E Jones \& Victor A Harris, “The Attribution of Attitudes” (1967) 3:1 J Experimental Social Psychology 1; Edward E Jones, Janet Morgan Riggs \& George Quattrone, “Observer Bias in the Attitude Attribution Paradigm: Effect of Time and Information Order” (1979) 37:7 J Personality \& Social Psychology 1230.

R v Ebanks, 2007 CanLII 23028, [2007] OJ No 2412 (QL) (Sup Ct J) cited to [2007] OJ No 2412 (QL). 
material facts,”230 made “intentional mis-statements, errors or omissions of material facts”231 and demonstrated a "reckless disregard for the truth."232 Justice MacPherson, overturning that decision, found the trial judge "imported elements of intent or purposefulness or elements of incompetence or disrespect for the court to the affiant's conduct ... [but] failed to point to any evidence for his contentions regarding the affiant's state of mind in making certain errors." 233

This importation of intent or purposefulness can be applied to any police action. Rather than attribute the officer's behaviour to situational factors (which the officer is likely to have interpreted in a manner unique to policing), the judge may misattribute the officer's behaviour to intentional actions based on a blatant disregard for the Charter or some other malfeasance. Such attributions go to the heart of any analysis on the exclusion of evidence under section 24(2) of the Charter. ${ }^{234}$ Over time, such misattributions can result in overall negative impressions about police officers. For instance, Alan Dershowitz stated that, as a rule of the American criminal justice system, "[a]lmost all police lie about whether they violated the Constitution in order to convict guilty defendants." 235 One would hope that is a gross exaggeration informed by years of falling victim to the fundamental attribution error.

\section{CONCLUSION}

It has been said that policing has become what the police want it to be. ${ }^{236}$ The same could be said of the court; it has become what the judges and lawyers want it to be. Both are monopolies. ${ }^{237}$ Given this monopolistic development against a backdrop of potential for disagreement, one may wonder if the two institutions are on divergent paths. I would say they are not, but due to inevitably different perspectives, processes, and purposes, the relationship is prone to unavoidable tension.

For police officers, understanding and reflecting on the factors which influence their behaviour can lead to recognition of the dangers and benefits of those influences, particularly as they impact later involvement with the courts. For the courts, understanding the difficulties in policing can lead to a better appreciation of the thought processes officers engage in, which may not be readily apparent in their testimony. The combination would serve as a bridge of understanding between these different constituencies.

Thus, the unavoidable tension between the police and the courts need not result in an antagonistic relationship, but rather it could serve as a stabilizing force to keep the system in balance. Indeed, this dynamic tension ought to act as a mechanism to correct gradual overreach by the police while simultaneously anchoring the courts to the practical reality of society that the entire justice system serves.

\footnotetext{
$230 \quad$ Ibid at paras 235, 262, 285.

$231 \quad$ Ibid at para 203.

$232 \quad$ Ibid at paras 237, 262, 287, 298.

$233 \quad R v$ Ebanks, 2009 ONCA 851, 249 CCC (3d) 29 at para 42.

$234 \quad$ Grant, supra note 196 at paras 72-75.

$235 \quad$ Alan M Dershowitz, The Best Defense (New York: Random House, 1982) at xxi.

$236 \quad$ Braiden, supra note 74 at 312.
}

237 Ibid at 315-17. 